\title{
An Economic Theory of Court Performance: Evidence from the Court of Justice of the European Union
}

\author{
Timothy Yu-Cheong Yeung ${ }^{a *}, \quad$ Michal Ovádek ${ }^{a \dagger}$ and Nicolas Lampach ${ }^{a \ddagger}$ \\ ${ }^{a}$ Centre for Legal Theory and Empirical Jurisprudence, KU Leuven
}

\begin{abstract}
We propose and test a new theory of court performance. Unlike most previous research on the economic performance of courts, we develop a simple formal model that emphasizes the existence of a trade-off between decision-making speed and quality. Drawing on neoclassical consumer choice theory, we presuppose that judges and courts derive utility from delivering quality decisions quickly while facing a budget constraint. We hypothesize that both quality and speed decrease as a consequence of growing backlogs, whereas the opposite effect should be observed if courts' resources increase. We apply an instrumental variable approach to disentangle the simultaneous determination of quality and speed and we estimate the effect of backlog and resources on both using an original dataset comprising the entire universe of cases brought before the Court of Justice of the European Union. We find robust evidence of a negative effect of backlog on both speed and quality but the theorized positive impact of increasing resources is less robust. We also find that the creation of new courts did not have the desired positive effect on speed but it did lead to an increase in quality.
\end{abstract}

Keywords: Court performance, Court of Justice, European Union, Instrumental variable approach, Judicial Speed, Reforms, Quality

JEL Classification: C23; D24; K41; O52

Acknowledgment The authors gratefully acknowledge financial support from European Research Council Grant No. 638154 (EUTHORITY).

\footnotetext{
* Corresponding author: Centre for Legal Theory and Empirical Jurisprudence, Faculty of Law, KU Leuven, Belgium. E-mail: yucheong . yeung@kuleuven . be, Tel:

$\dagger$ Centre for Legal Theory and Empirical Jurisprudence, Faculty of Law, KU Leuven, Belgium. Email: michal . ovadek@kuleuven. be

$\ddagger$ Centre for Legal Theory and Empirical Jurisprudence, Faculty of Law, KU Leuven, Belgium. E-mail: nicolas. lampach@kuleuven. be
} 


\section{An Economic Theory of Court Performance:}

\section{Evidence from the Court of Justice of the European Union}

We propose and test a new theory of court performance. Unlike most previous research on the economic performance of courts, we develop a simple formal model that emphasizes the existence of a trade-off between decision-making speed and quality. Drawing on neoclassical consumer choice theory, we presuppose that judges and courts derive utility from delivering quality decisions quickly while facing a budget constraint. We hypothesize that both quality and speed decrease as a consequence of growing backlogs, whereas the opposite effect should be observed if courts' resources increase. We apply an instrumental variable approach to disentangle the simultaneous determination of quality and speed and we estimate the effect of backlog and resources on both using an original dataset comprising the entire universe of cases brought before the Court of Justice of the European Union. We find robust evidence of a negative effect of backlog on both speed and quality but the theorized positive impact of increasing resources is less robust. We also find that the creation of new courts did not have the desired positive effect on speed but it did lead to an increase in quality.

Keywords: Court performance, Court of Justice, European Union, Instrumental variable approach, Judicial Speed, Reforms, Quality

JEL Classification: C23; D24; K41; O52

Acknowledgment The authors gratefully acknowledge financial support from European Research Council Grant No. 638154 (EUTHORITY). 


\section{Introduction}

In recent years economists have become increasingly interested in the efficiency of courts and the impact of workload and staff on judicial decision-making. While some scholars attest to a positive relationship between judicial resources and court productivity (Djankov et al., 2003; Rosales-López, 2008; Gomes et al., 2016; Mitsopoulos and Pelagidis, 2010), others show exactly the contrary (Beenstock and Haitovsky, 2004; Dimitrova-Grajzl et al., 2012). Although some hints and clues partially explaining this divergence were advanced in the literature, a more comprehensive theoretical and empirical effort is necessary to illuminate the fundamentals of economic performance of courts.

The efficiency of court systems is of great interest to public administrations everywhere, all the more so given pressures on reducing public spending. The balancing of several variables, from demand for quick dispute resolution to the necessary staffing levels, is key to judicial management and court system planning (Engel and Weinshall, 2019; Gomes et al., 2016; Voigt, 2016). Dysfunctional and arbitrary judiciaries have proven to have serious economic consequences for growth and businesses. In many countries in the world, courts accumulate large backlogs with the consequence of increasing delays, which downstream impact negatively both litigants and public trust in the judiciary (Cabrillo and Fitzpatrick, 2008). Dilatory judicial proceedings increase uncertainty among economic actors and thus impede economic activity. This worldwide problem has received widespread attention in international fora such as the European Union (EU), Council of Europe, Organisation for Economic Co-operation and Development (OECD) and World Bank, all of which have urged action to combat judicial delay and improve the efficiency of court systems (Falavigna et al., 2015; Henisz, 2000; Marciano et al., 2019; Melcarne and Ramello, 2016; Weder, 1995).

Although these issues are hardly new, economic studies began only recently to unpack the determinants of judicial performance. Advocates of the exogenous productivity hypothesis of judges argue that a higher number of files on the court docket will motivate judges to increase their efficiency in resolving cases (Beenstock and Haitovsky, 2004; Dimitrova-Grajzl et al., 2012). This argument suggests that the self-regulating mechanism of production prevents the explosion of growth but critics have pointed to variables missing from the theory, most notably judicial and institutional constraints (Jonski and Mankowski, 2014; Gomes et al., 2016). Along with this criticism one can plausibly argue that where judicial output grows with increasing backlog, it can only do so at the expense of quality. Studying court performance, moreover, requires taking into account frequent shifts in resources - such as budget, staff or information technology systems - available to courts. Such changes are 
liable to impact backlog, speed and quality at the same time.

In an attempt to shed light on the effect of backlogs and resources on the economic performance of courts, we draw on consumer choice theory to model the dynamics of the trade-off between quality and speed of judicial outcomes under a budget constraint. Compared to extant literature, this model has the distinct advantage of at once acknowledging that court performance is constrained by available resources while also incorporating, in line with real-world preoccupations, decision-making speed rather than the sheer quantity of decisions produced as a core theoretical component. We test our theory of court performance on an original dataset comprising the entire universe of cases brought before the Court of Justice of the European Union (1953-2017). We apply an instrumental variable approach by using lagged average speed as an instrument for speed to disentangle the simultaneous determination of quality and speed. Our empirical findings support the existence of a trade-off between quality and speed in court decisions, as well as the hypothesis that backlogs exert a negative effect on speed and quality, contrary to the prediction of the exogenous productivity hypothesis. We find only weak evidence of a positive effect of expenditure on speed but stronger support for its impact on quality. Finally, we find that the establishment of new courts had only a small to no positive impact on speed, contrary to the expectations of policy-makers, although the reforms did lead to an improvement in terms of quality.

The remainder of this paper is divided into six sections. The next section presents our theoretical model of court performance. Subsequently, we introduce the Court of Justice of the European Union and its own struggles with speed and quality. Section 4 provides an overview of the data, followed by an explanation of the empirical strategy in Section 5 where we also present the main results before concluding with a summary of our main findings.

\section{Trade-off between Speed and Quality}

Inspired by consumer choice theory, we model court performance as a trade-off dynamic between decision-making speed and quality under a budget constraint. This approach is different from Vereeck and Mühl (2000) who focus exclusively on the demand side of litigation and more related to Falavigna et al. (2015); Beenstock and Haitovsky (2004); Bielen et al. (2018); Dimitrova-Grajzl et al. (2012) who examine court performance through the lens of frontier production analysis. What many studies have, nonetheless, in common is that their main dependent variable of interest is the sheer number of cases resolved by courts. We argue that the "quantitative" aspect of court performance should instead be measured in terms of time needed to resolve a case. The choice 
of speed as one of the key dimensions along which court performance is measured is in line with the focus of international organizations, domestic institutions, litigants and courts themselves, all of whom are much more preoccupied by how long it takes to resolve cases rather than how many are resolved in absolute numbers. Recognizing its relevance, some authors have adopted speed as a rough proxy for judicial efficiency (Binford et al., 2007; Cauthen and Latzer, 2008; Dalla Pellegrina, 2008).

Speed is, however, not the only factor of concern for judges and litigants. A much more difficult to quantify, yet necessary, aspect of judicial decision-making is quality. A well-reasoned court decision is much more likely to reduce economic uncertainty, at minimum between litigating parties and potentially with system-wide positive externalities (Marciano et al., 2019). On the contrary, a poorly reasoned or otherwise confusing judgment is liable to create or contribute to uncertainty. Hard as it may be to strip away the multifaceted nature of quality (Tyler, 2001; Colombet and Gouttefangeas, 2013; Basabe-Serrano, 2016), its importance is underscored by the overwhelmingly qualitative nature of discussions in legal communities which shape judicial reputations and legacies. Judges and lawyers care about decision-making quality but they might struggle to articulate what it entails exactly, which presents measurement difficulties. Scholars attempting to grasp quality quantitatively have turned to the number of times a decision is appealed and variation in decision types as proxies (RosalesLópez, 2008; Engel and Weinshall, 2019) but the former is not universally applicable (not all decisions can be appealed), while the latter offers only limited granularity (there are usually only a handful of decision types) and can be overly influenced by procedural idiosyncrasies particular to a given legal system. As a result, we use instead the length of court decisions, measured in number of words, as a proxy indicator for quality. Longer decisions require more effort and signal depth of argumentation. Length is typically correlated with decision type but as a continuous variable encodes more information about quality. It is also a more universal measure than looking at appealed and overturned decisions.

Given the limited amount of available resources and time, judges therefore face a trade-off: reduce decisionmaking speed and deliver higher quality or increase speed at the expense of quality. We develop a simple analytical model to capture this trade-off. A judge generates positive utility from producing fast and highquality decisions, perhaps due to reputational rewards. More formally, we denote the judge's utility function by $U(Q, S)$ and assume it to be concave over $Q$ and $S$, i.e. $U_{Q}>0, U_{Q Q}<0, U_{S}>0$ and $U_{S S}<0$. For the sake of simplicity we suppose demand for dispute resolution is exogenous, although in reality a positive feedback loop might exist in some situations between court performance and demand. 
The reason why judges face a speed-quality trade-off in the first place is that their capacity to resolve disputes is constrained by the level of resources (e.g. budget, staff, information technologies) given at their disposal. Moreover, they are typically under a constant load of pending cases - what we term the "backlog" (or "caseload") - that require resolution and therefore an allocation of scarce resources. Together, resources $K$ and backlog $L$ constitute the constraint along which a preferred mix of speed and quality of decision-making is chosen. A unit of resources per case allows case resolution at speed $K / L$ given a minimum level of quality $(Q=0)$. For example, if a judge has ten cases on the docket and ten units of resources available, the speed equals one if and only if the quality is set at the minimum level $(Q=0)$ and all resources are used up. If the judge wishes to improve quality per case by one unit, s/he has to pay a price $p$, which can also be interpreted as the technical or institutional trade-off ratio between quality and speed or the relative price of quality. The cost incurred in doing so is, $p Q$, and speed falls as a result, $1-p<1$. $^{1}$ We generalize the budget constraint as follows:

$$
\frac{K}{L}=S+p Q
$$

The budget constraint defines the limits subject to which judges maximize their utility. Replacing $S$ by the budget constraint, the utility function becomes $U(Q, K / L-p Q)$. The first-order-condition (FOC) and the second-order-condition (SOC) are the following:

$$
\begin{gathered}
-p U_{S}+U_{Q}=0 \\
p^{2} U_{S S}+U_{Q Q}-2 p U_{Q S}<0
\end{gathered}
$$

Including the equilibrium choices of $Q$ into the FOC and then total differentiating the FOC with respect to $K$ we obtain the following comparative statics:

$$
\frac{\partial Q^{*}}{\partial K}=\frac{1}{L} \frac{p U_{S S}-U_{Q S}}{S O C}
$$

\footnotetext{
${ }^{1}$ Although we illustrate the model on judges, the decision-maker can also be the court deciding on the average level of quality and speed.
} 
and

$$
\frac{\partial S^{*}}{\partial K}=\frac{1}{L}-p \frac{\partial Q^{*}}{\partial K}
$$

No assumption has hitherto been made about the cross derivative $U_{Q S}$. If they are q-complements (Seidman, 1989) then $U_{Q S}$ is positive implying that $\partial Q^{*} / \partial K$ is also positive. Increasing resources shifts the budget constraint outward which leads to higher quality in most cases (see Figure 1).

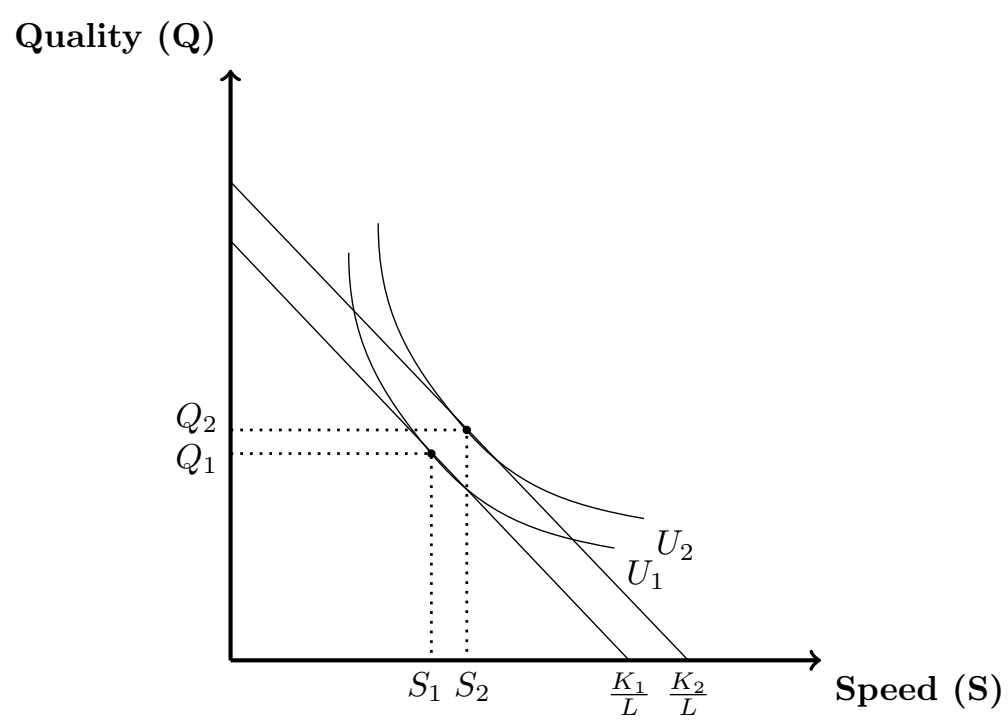

Figure 1: Effect of Resources on Quality and Speed

Note: An increase in resources, from $K_{1}$ to $K_{2}$, shifts the budget line outward. The shift increases speed from $S_{1}$ to $S_{2}$ and quality from $Q_{1}$ to $Q_{2}$. However, our assumptions do not rule out the possibility that one of the two goods would fall as a result of an increase in resources.

In some rare circumstances, the cross derivative might be negative. In that case the sign of $\partial Q^{*} / \partial K$ depends on the relative price of quality. If $p$ is very small - close to zero - then $\partial Q^{*} / \partial K<0$. As $p$ increases, $p U_{S S}$ will at some point be larger than $U_{Q S}$ and $\partial Q^{*} / \partial K$ will become positive. The cross partial derivative $U_{Q S}$ is usually positive for a large class of utility functions - such as the Cobb-Douglas utility function.

At a relatively low price of quality, the marginal change in resources increases judicial speed $\left(\partial S^{*} / \partial K>0\right)$. This outcome is the most likely. We would expect that an outward shift in the budget constraint enhances both speed and quality. An arguably less likely situation arises when $p$ is very high, in which case $\partial S^{*} / \partial K$ can be negative if the court spends an amount on quality that is even larger than the increase in resources. In other words, quality is an inferior good in this scenario.

We can similarly derive the comparative statics with respect to $L$ as follows: 


$$
\frac{\partial Q^{*}}{\partial L}=\frac{-K}{L^{2}} \frac{p U_{S S}-U_{Q S}}{S O C}
$$

and

$$
\frac{\partial S^{*}}{\partial L}=\frac{-K}{L^{2}}-p \frac{\partial Q^{*}}{\partial L}
$$

An increase in backlog $L$ shifts the budget line inward, that is in exactly the opposite direction to a budget $K$ increase. We therefore expect $Q$ and $S$ to fall as a result of a rise in $L$.

Furthermore, we derive the following comparative statics with respect to $p$ :

$$
\frac{\partial Q^{*}}{\partial p}=\frac{U_{S}+p Q\left(p U_{S S}-U_{Q S}\right)}{S O C}
$$

and

$$
\frac{\partial S^{*}}{\partial p}=-Q^{*}-p \frac{\partial Q^{*}}{\partial p}
$$

According to the Law of Demand, $\partial Q^{*} / \partial p$ should be negative. ${ }^{2}$ Meanwhile, $\partial S^{*} / \partial p$ is positive only if the income effect $\left(Q^{*}\right)$ is smaller than the substitution effect $\left(-p \frac{\partial Q^{*}}{\partial p}\right)$. Given a constant level of resources, an increase in the price of quality rotates the budget line inward, as shown in Figure 2.

\section{Quality (Q)}

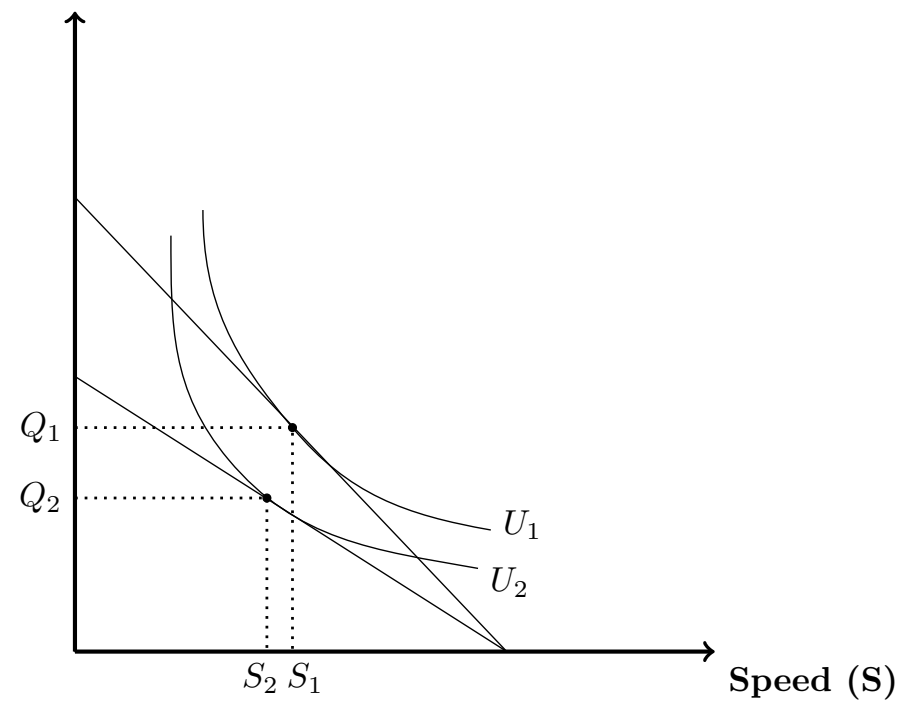

Figure 2: Rotation of the Budget Constraint: Effect of Price on Quality and Speed

Note: An increase in $p$ rotates the budget line inward. As a result, the utility level falls from $U_{1}$ to $U_{2}$. Even if we constrain the scenario so that $Q$ decreases as a result of an increase in price, we cannot determine whether $S$ would increase or decrease. The figure shows only one possibility.

\footnotetext{
${ }^{2}$ We assume away the possibility of a Giffen good.
} 
In general, by Law of Demand quality should fall following a rise in price. Speed, however, may or may not increase (see Figure 2). The substitution effect caused by a higher cost of quality $p$ accelerates judicial decision-making but the negative income effect may offset even entirely the positive effect. ${ }^{3}$

In summary, we propose a necessary condition and two testable hypotheses on the basis of our theoretical model:

- $\mathbf{C}_{\mathbf{1}}$ Average quality and speed are negatively correlated, holding other factors constant.

- $\mathbf{H}_{\mathbf{1}}$ Average quality and speed fall as a result of an increasing backlog, holding other factors (including level of resources) constant.

- $\mathbf{H}_{2}$ Average quality and speed increase as a result of more resources being available, holding other factors (including the backlog level) constant.

We assess the necessary condition and theoretical predictions empirically with an application on the Court of Justice of the European Union. The next section provides background information on the judicial system of the European Union.

\section{Application: Court of Justice of the European Union}

The Court of Justice of the European Union (CJEU) is one of the most well-known international courts in the world and a chief actor in the process of European integration since the latter's beginning. Reflecting the most advanced state of European integration among regional integration organizations worldwide, the term "supranational" might be more appropriate than "international", as the Court was set up from the start to partially mimick domestic courts (Valentine, 1955). Despite several changes to its official name, the Court is in continuous operation since December 1952 when it opened for business at the villa Vauban in Luxembourg as the Court of Justice of the European Coal and Steel Community. Although the Court has since relocated into premises many times larger (villa Vauban is now an art museum), and undergone changes commensurate with the expansion of European integration, the point of origin for all successive institutional developments is late 1952, which makes it one of the oldest EU institutions. ${ }^{4}$

\footnotetext{
${ }^{3}$ Note that the relative price of quality $p$ is a latent variable that cannot be directly observed.

${ }^{4}$ The core institutions of the European Coal and Steel Community - the High Authority (nowadays the Commission), the Council (composed of the Member States) and the Assembly (nowadays the European Parliament) began operation during the autumn of 1952, after the establishing Treaty of Paris entered into force on 23 July 1952.
} 
Both the composition of the Court and potential avenues for reaching it have changed considerably since its establishment. The Court started off with less than fifty staff members and seven judges. Nowadays it has over 1500 staff and 74 judges divided across two levels of jurisdiction, the Court of Justice (the highest, traditional instance) and the General Court (a first instance court). The legal structure determining what pathways are available for a case to reach the Court has also changed over time, albeit less drastically. In the following paragraphs we introduce briefly the main features of the Court's composition and provide an exposé of the four most important judicial procedures which generate $95 \%$ of the Court's caseload.

\subsection{Composition}

What is nowadays referred to as the Court of Justice of the European Union consists in fact of two courts: the Court of Justice and the General Court. The Court of Justice is the court longest in existence and it has always occupied the highest position in the EU judicial hierarchy. The General Court was established in 1989 in response to mounting caseload as the Court of First Instance. A third, specialized court called the Civil Service Tribunal existed between 2005 and 2016; its workload has now been transferred to the General Court which has additionally had its number of judges raised from 28 to 56 to tackle increasing case delay.

Judges are appointed for a renewable term of 6 years by consensus of the Member States. The latter have never blocked the appointment of any judge, although a new committee which vets each judge's credentials (behind closed doors) was established following the Lisbon Treaty revision in 2010. The committee's in theory non-binding recommendations regarding appointments have so far been always respected. The CJEU moreover includes so-called Advocates-General who draft opinions on important cases; in a majority of cases the Court follows these opinions in its judgments.

Judges and Advocates-General are aided in every-day work by the registry, which manages the administrative aspects of case handling, and law clerks working in chambers of the respective court members (Zheng, 2016; Krenn, 2018). Judges can also draw on institutional resources, notably research services, which provide ondemand support. Both the Court of Justice and the General Court elect their own President - with the former leading the hierarchy - who are responsible for representing the institution externally and managing key aspects of judicial work, such as case allocation, internally. 


\subsection{Judicial Procedures}

The primary role envisaged for the Court in the institutional framework of the Coal and Steel Community was to control the decisions of the executive body, the High Authority (the Commission), when these were disputed by the Member States or affected private parties. ${ }^{5}$ This pathway to the Court is called the "annulment procedure", because the plaintiff aims to annul a decision of an EU institution. The procedure was modelled upon the French system of administrative law review (Koopmans, 1991). ${ }^{6}$ It has persisted in similar forms since, ${ }^{7}$ with the main change relating rather to the increasing number of issue areas in which EU institutions - not only the Commission - render decisions.

The Treaty of Rome, signed in 1957, brought about many institutional changes, notably by expanding the policy remit of the nascent EU beyond coal and steel. But the most important change for the CJEU concerned the introduction ${ }^{8}$ of a new judicial procedure. Article 177 (now Article 267 TFEU) enabled national courts in the Member States to refer questions about EU law to the CJEU. Although the procedure was not used during the first two and a half years it had been in force, it has since become the main source of the CJEU's workload and in qualitative terms one of the most important interfaces through which European (legal) integration transpires (Rasmussen, 2014; Weiler, 1994; Alter, 1998; Dyevre et al., 2019). Despite the fact that the Treaty more or less obliges national courts whose judgments cannot be appealed to send preliminary references to Luxembourg, in practice a host of other factors impede the uniform application of EU law in the Member States (Lampach and Dyevre, 2019).

Third, the EU legal system has since its inception provided for the possibility to prosecute Member States which fail to respect EU law obligations. ${ }^{9}$ Next to the Court the key actor in this procedure - called "infringement proceedings" - is the Commission. The Commission is charged with monitoring - and if necessary, enforcing, via the Court - Member State compliance with EU law. As a result, the caseload flowing through this judicial avenue is going to largely depend on the Commission priorities and strategic behaviour and to a lesser extent on the compliance record of the Member State (Fjelstul and Carrubba, 2018).

Fourth, the EU judiciary has since the beginning been in charge of adjudicating actions concerning civil service matters. Typically these cases involve an EU civil servant complaining about their employment conditions

\footnotetext{
${ }^{5}$ See Articles 33 and 37 of the Treaty establishing the European Coal and Steel Community.

${ }^{6}$ French influence is felt more generally at the Court, seeing as it is also its main working language.

${ }^{7}$ See Article 263 of the Treaty on the Functioning of the European Union (TFEU).

${ }^{8} \mathrm{~A}$ rudimentary and vague allusion to a similar procedure was already included in Article 41 of the Treaty establishing the European Coal and Steel Community.

${ }^{9}$ Originally Article 88 of the ECSC Treaty; now Article 258 TFEU. The Treaty of Rome (Article 169) adjusted this procedure in 1958 by shifting the burden of initiating a court case from the Member State on the Commission and by allocating the power to impose financial penalties to the Court.
} 
with one of the EU institutions. From a broader political or economic perspective, this line of cases is therefore among the qualitatively less important, albeit considerable in number. Originally, the Court of Justice alone was in charge of dealing with civil service cases; later the bulk of this responsibility was transferred to the Court of First Instance (now the General Court) after which a specialized court, the Civil Service Tribunal, was set up to ease the burden on the Court of Justice and the General Court. Following a major reform in 2016, the Civil Service Tribunal was disbanded and the General Court is back in charge of staff cases.

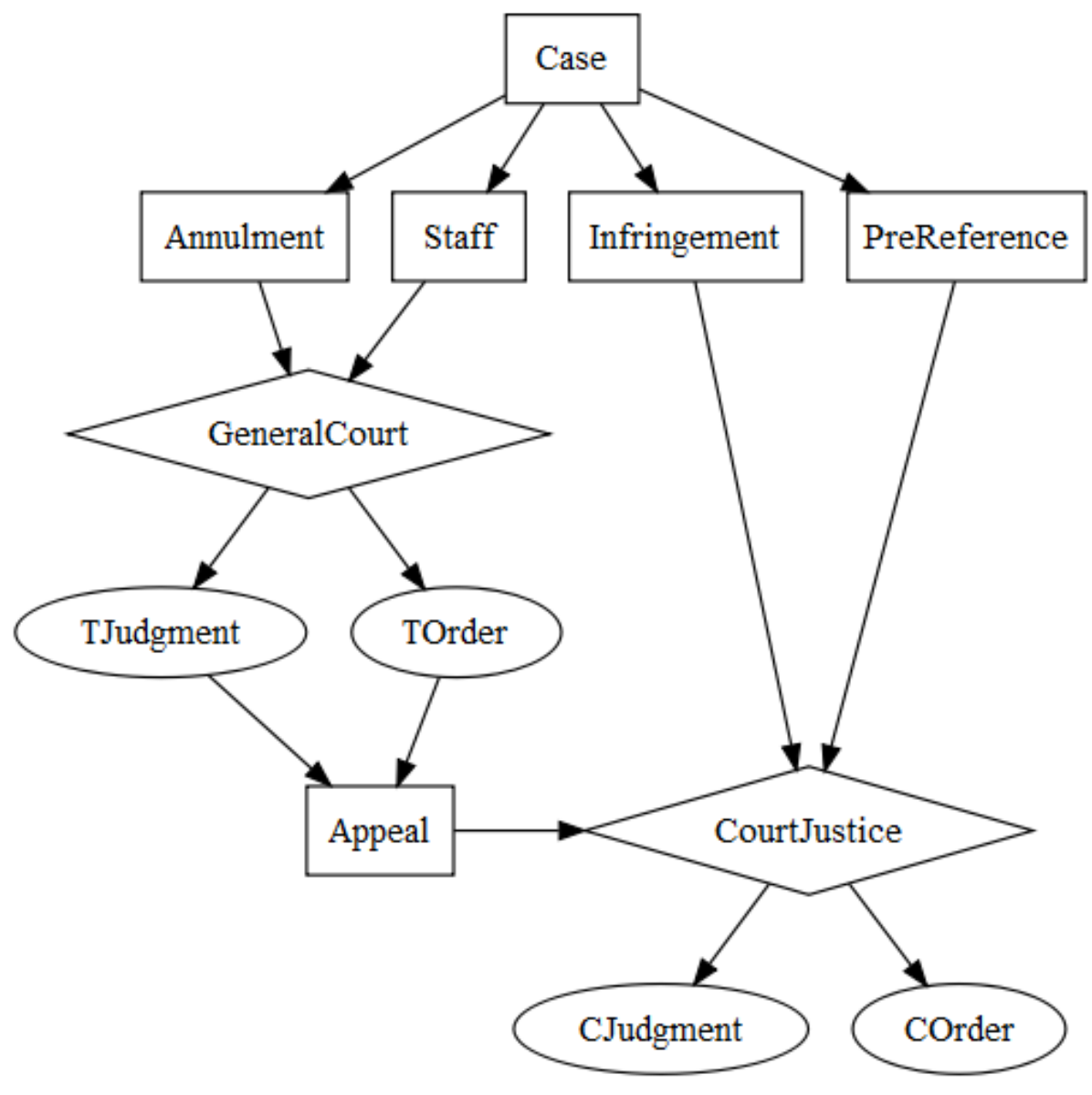

Figure 3: Types of cases and judicial outcomes

Note: Other judicial procedures are excluded from the flowchart due to their relatively rare application. In addition, in a limited number of annulment cases (those which are inter-institutional) the dispute goes directly in front of the Court of Justice.

Although there is a myriad of other judicial procedures - such as third-party proceedings or applications for interim relief - these are used relatively rarely compared to the four main types of cases outlined already. With the exception of opinions on the conclusion of international agreements, which can be requested by EU institutions, the outcomes of these other types of cases are generally also less consequential than the main procedures. Moreover, a common procedural measure involves the joining of several cases together for the 
purposes of judicial deliberation and/or issuing a single judgment.

In the majority of cases CJEU judges choose between deciding a case by a judgment or by an order. Both are similar in form but orders are typically much shorter and less time-intensive. Case files which are discontinued or otherwise manifestly unworthy can be closed by an order with as few as two sentences. Judgments, on the other hand, should engender fully-fledged resolutions of disputes, albeit they, too, can vary from a few pages to several hundred depending on case and judicial discretion. Most cases filed at the first instance - i.e. with the General Court - can subsequently be appealed on points of law to the Court of Justice which can confirm or overturn the original decision. The decisions of the Court of Justice cannot be appealed before any other court, similarly to the Supreme Court of the United States. Unlike the SCOTUS, however, the Court of Justice - nor the General Court - can select cases for which it will render judgments. This lack of direct docket controlling power makes the CJEU a more representative object of inquiry, as the vast majority of domestic and international courts must dispose of all cases put in front of them.

\subsection{Delay and reforms}

One reason the EU judiciary offers an appropriate ground to test our theory of economic performance are the organizational interventions the CJEU attracted due to increasing delays. The original single-instance system was transformed into a two-tiered one in 1989 with insiders describing the growing backlog and delay as "unmanageable" (Slynn, 1989; Van Ginderachter, 1989; Kennedy, 1989; Jacqué and Weiler, 1990). The causes and potential consequences discussed are not difficult to guess: the EU was expanding both geographically and in terms of policy remit, in particular with a possible deluge of internal market laws on the horizon at the dawn (1985) of the Single European Act agenda (Easson, 1989; Schermers, 1988, 547). A chief concern was that an increasing length of proceedings would discourage national courts from submitting preliminary references which even today are critical to the practical application of EU law in the Member States. ${ }^{10}$ Conversely, it was hoped that a separate first-instance court dealing with fact-heavy cases could improve the quality of decisions (Slynn, 1989; Van Ginderachter, 1989), which according to some was already falling at the time (Jacqué and Weiler, $1990)$.

The respite, if any, was temporary and by 2000 the talk was of a "crumbling judicial system" due to the rising backlog and delay (Rasmussen, 2000; Turner and Muñoz, 2000; Forwood, 2000; Scorey, 1996). After years of

\footnotetext{
${ }^{10}$ Underlining the practical relevance of our theoretical lens, some national judges' preferences over the quality-speed continuum were later revealed when they were quoted as willing to accept slower replies from the Court of Justice as long as a high level of quality was maintained (Turner and Muñoz, 2000, 91).
} 
deliberation and two Treaty reforms, the EU opted to establish a third court in 2005, the Civil Service Tribunal (Lavranos, 2005). ${ }^{11}$ The General Court, in particular, was by then seriously struggling to juggle the fact-heavy competition cases with the sheer number of other cases, including staff complaints, while the duration of the sacrosanct preliminary ruling procedure kept increasing. An amendment to the EU constitutional framework led to the addition of a specialized tribunal to the existing judicial architecture. The choice of staff cases as the subject matter of the specialization was facilitated by the perception that this area of law did not directly affect the Member States - the key principals in the EU political system - but was rather internal in nature (Butler, 2019).

Nonetheless, the Civil Service Tribunal itself was sacrificed in the negotiations of the latest judicial reform as part of a political compromise that saw the number of General Court judges double and its agenda reabsorb staff disputes. This 2015 reform was described as both "radical" and "questionable" (Sarmiento, 2017; Alemanno and Pech, 2017) but it again came on the back of concerns about the effectiveness of the EU judiciary (van der Woude, 2012; Hadroušek and Smolek, 2015). It was prompted by excessively delayed competition cases in which a group of plaintiffs successfully sued the General Court for taking too long to render decisions, resulting in several damages awards (Ovádek, 2017). We are not yet able to observe the full impact of this organizational intervention but it attests to the continuing pertinence of concerns about delay and their non-negligible political salience.

A common theme running through the preceding storyline is that none of the interventions was accompanied by a rigorous econometric analysis of judicial performance (Alemanno and Pech, 2017). This provides further justification to supplant existing narratives with a theoretically informed inquiry of court data. That efficiency requires a solid information base was confirmed by a recent audit of the CJEU conducted by the Court of Auditors (a dedicated EU auditing institution) (European Court of Auditors, 2017). Limitations owing to document secrecy and data availability constrained the auditors' examination to less than 3000 cases. Our macro analysis of the CJEU's resource constraints and backlog speaks directly to observers interested in the Court's overall economic performance, in addition to providing a testing ground for our theoretical model.

\footnotetext{
${ }^{11}$ Interestingly, a staff tribunal was deemed desirable by the Council as early as 1974 (Schermers, 1988, 542)
} 


\section{Data}

We build a dataset comprising the entire universe of cases decided by the CJEU since its inception (1953-2018, $n=37538$ ). Contrary to existing datasets (e.g. Dyevre et al. (2019); Pavone and Kelemen (2019)), which focus either on a single procedure, period or only include judgments, ours is the first one to paint the full picture of the Court's workload at any point in time during its existence. We source all data from publicly available information on CJEU cases. ${ }^{12}$

At the case-level we collect data on court (Court of Justice, General Court, Civil Service Tribunal), procedure (annulment, staff, infringement, preliminary reference), decision (judgment, order), decision length in words, whether a case was joined with others and time from submission to decision. Due to missing information we imputed several thousand observations relating to submission date (NA = 13 052) and decision length (NA = 11 589). For submission dates we leverage the fact that cases are numbered sequentially in the order received by the Court. We assign a random date between previous and subsequent data point to a missing observation. We allow for this imputation only when the number of cases received in a year is above 100 (the rest collected manually), so that the target time window is never larger than two weeks and usually amounts to less than a week. Missing word counts are filled with averages of matching observations (by decision and procedure types). Figure 4 shows the comparison of time effort and count of words (both imputed) over time.

\footnotetext{
${ }^{12}$ The raw information is available on the websites of the CJEU and the EU's law portal: https://curia.europa.eu and https: //eur-lex.europa.eu.
} 


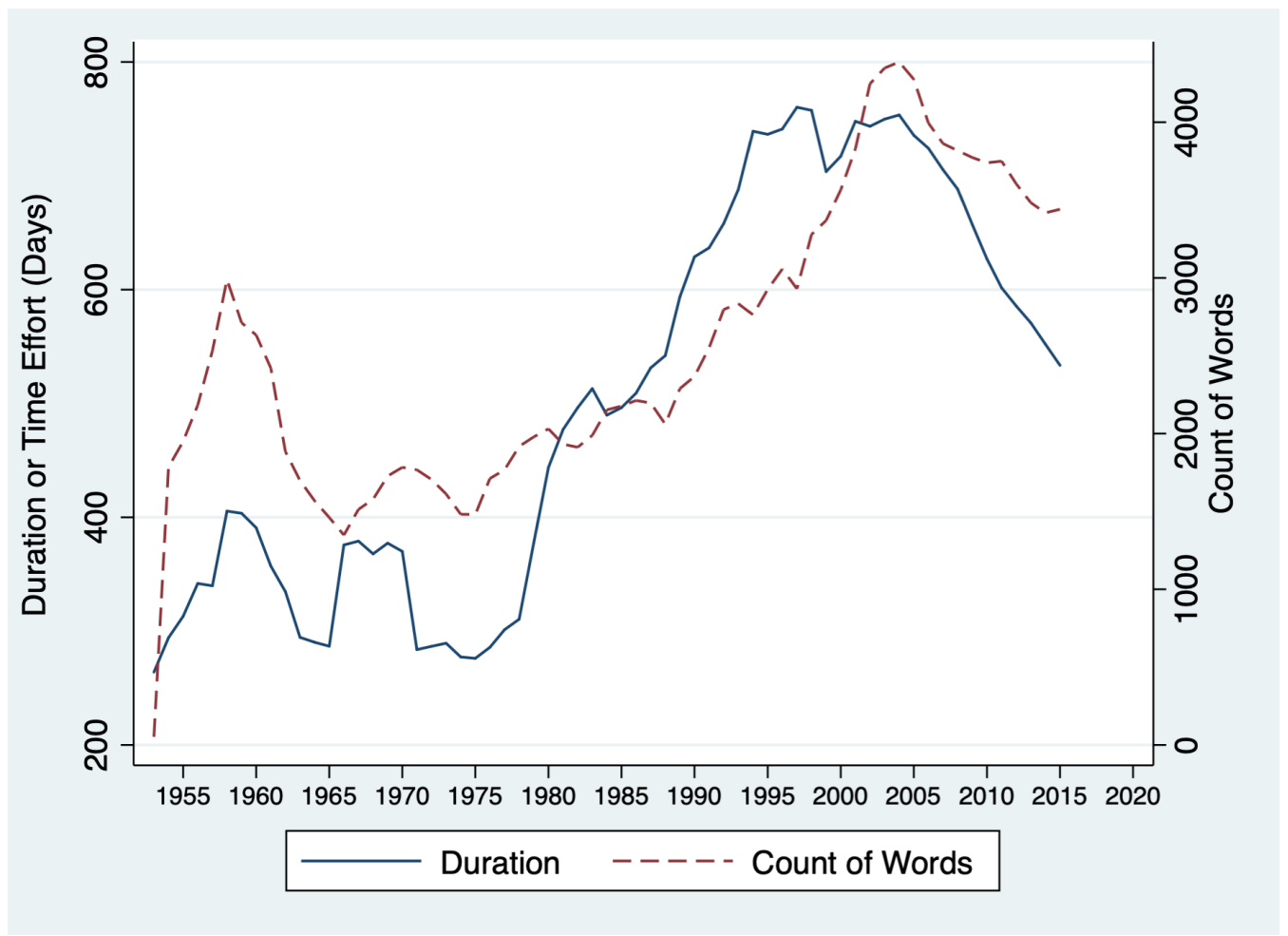

Figure 4: Comparison of average time effort and number of words per year

Note: Moving averages (4 lags plus current with equal weights) are shown instead of the actual data to avoid overplotting.

As mentioned previously, each case can be closed by either an order or a judgment. Nonetheless, we identify additional variation in decision type: a case can be removed by an order from the docket with minimal justification or it can be joined with other similar cases. Removals occur for example when a case is withdrawn by the plaintiff but also when the Court deems it overwhelmingly inadequate to warrant deliberation. Figure 5 plots the proportion of each decision type over time, as well as the total number of cases received in each year. 


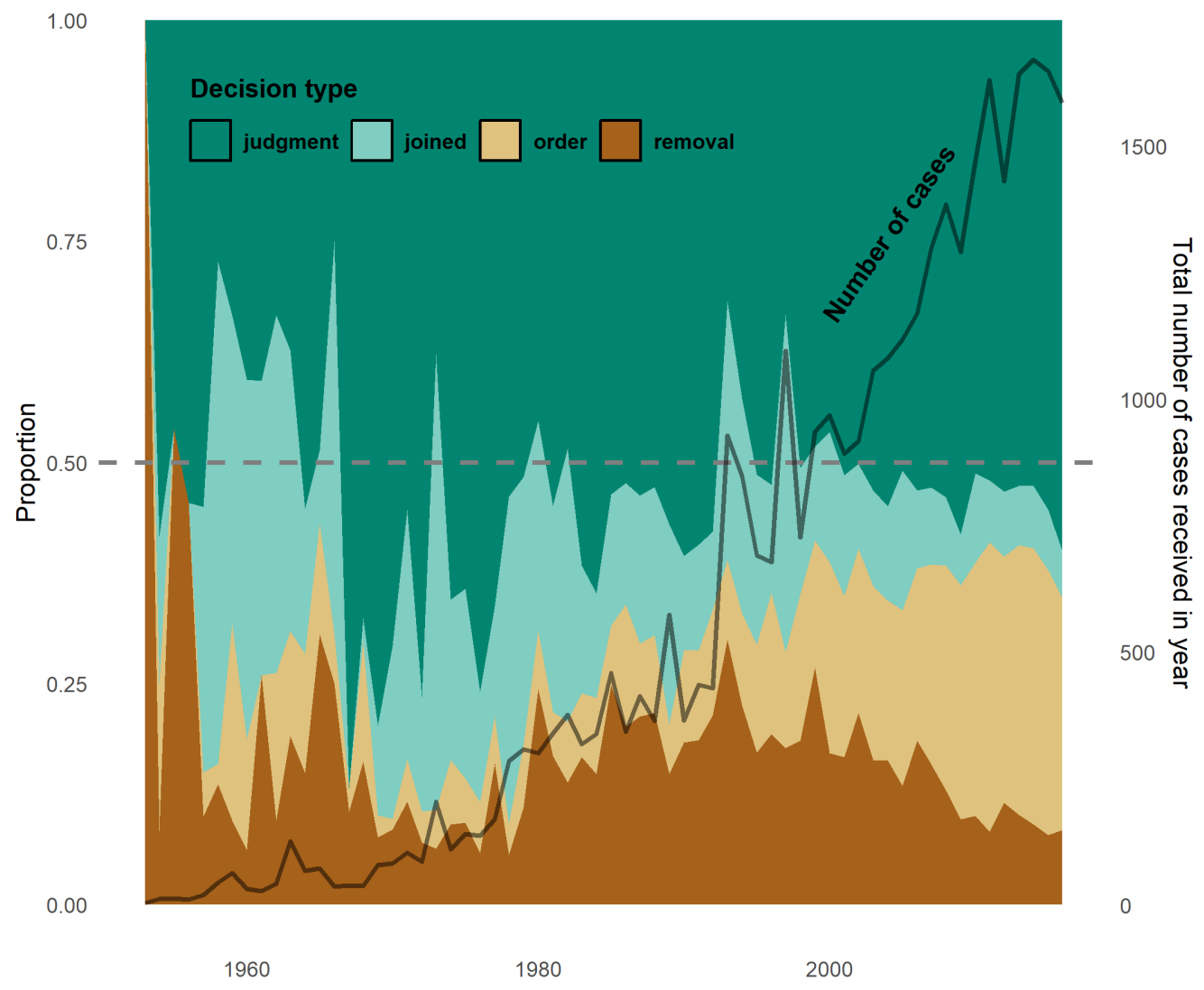

Figure 5: Share of different decision types and total number of cases received in year (1953-2016).

Note: The year axis measures the year when a case was filed at the Court. The left axis shows the proportion of the various types of decisions (colored area), while the right axis shows the total number of cases received in a year (dark line).

From the case-level information we further compute the number of new cases received, the number of cases resolved and the backlog at each moment in time. Although the number of cases closed per day increases over time, the backlog (additive sum of open cases) has been growing for decades and started to decrease only in recent years. 


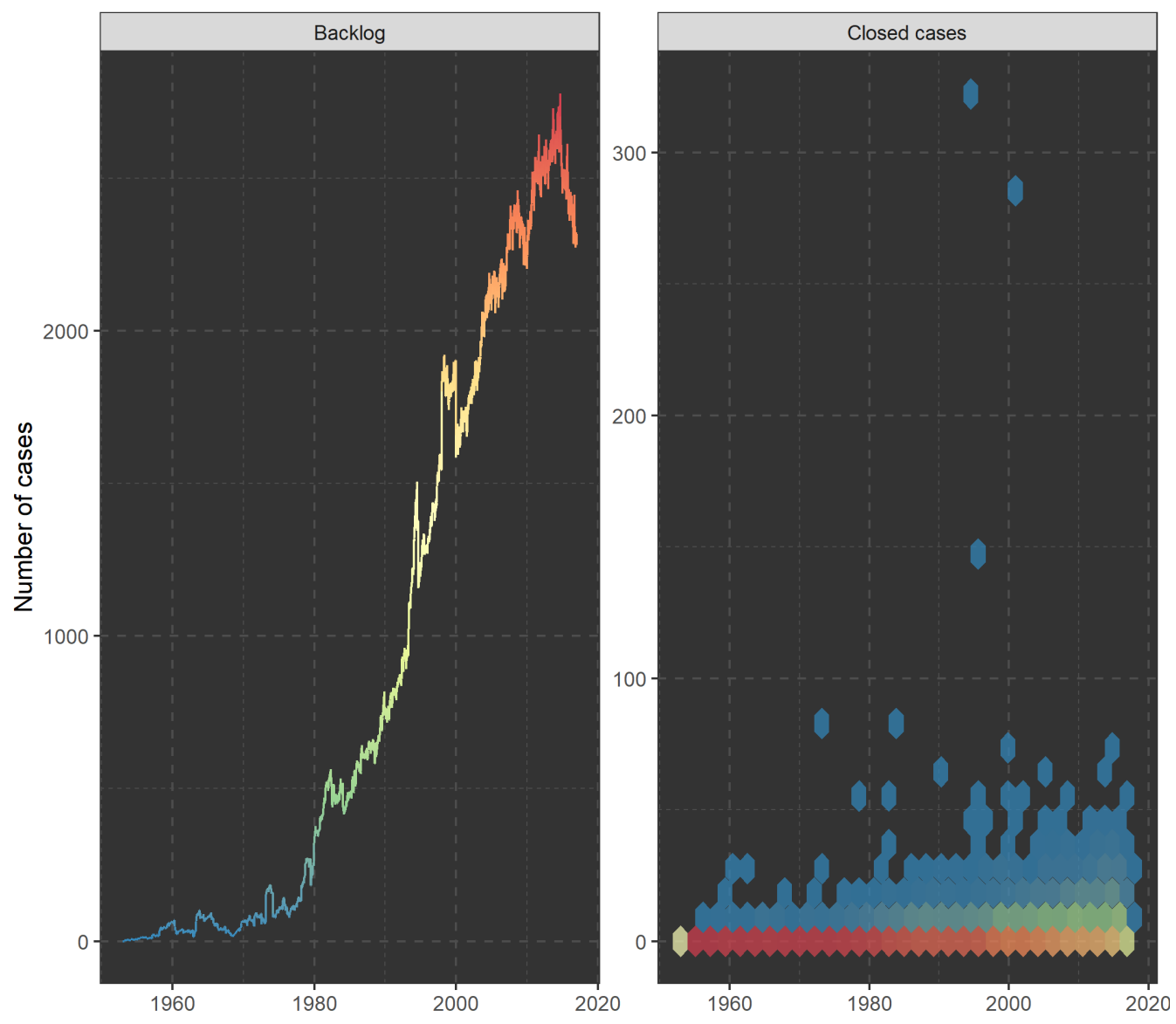

Figure 6: Backlog size and number of cases closed by the CJEU on each day (1953-2016).

Note: Color indicates number of cases per day for backlog and density of number of decisions for closed cases.

On the input side we collected information on the budget of the CJEU and the number of sitting judges, both reported at the year level. Budgetary information is taken from the official accounts of the EU at the moment when the final amount of expenditure is definitively closed (two years after the budgetary year), with the exception of 2018 and 2019 for which only intermediate projections exist yet. Similarly to the budget, the number of judges has also been steadily increasing over the years. Judges were added at various junctions rather than on a year-by-year basis, notably when the EU expanded its membership or when a new court was created. 

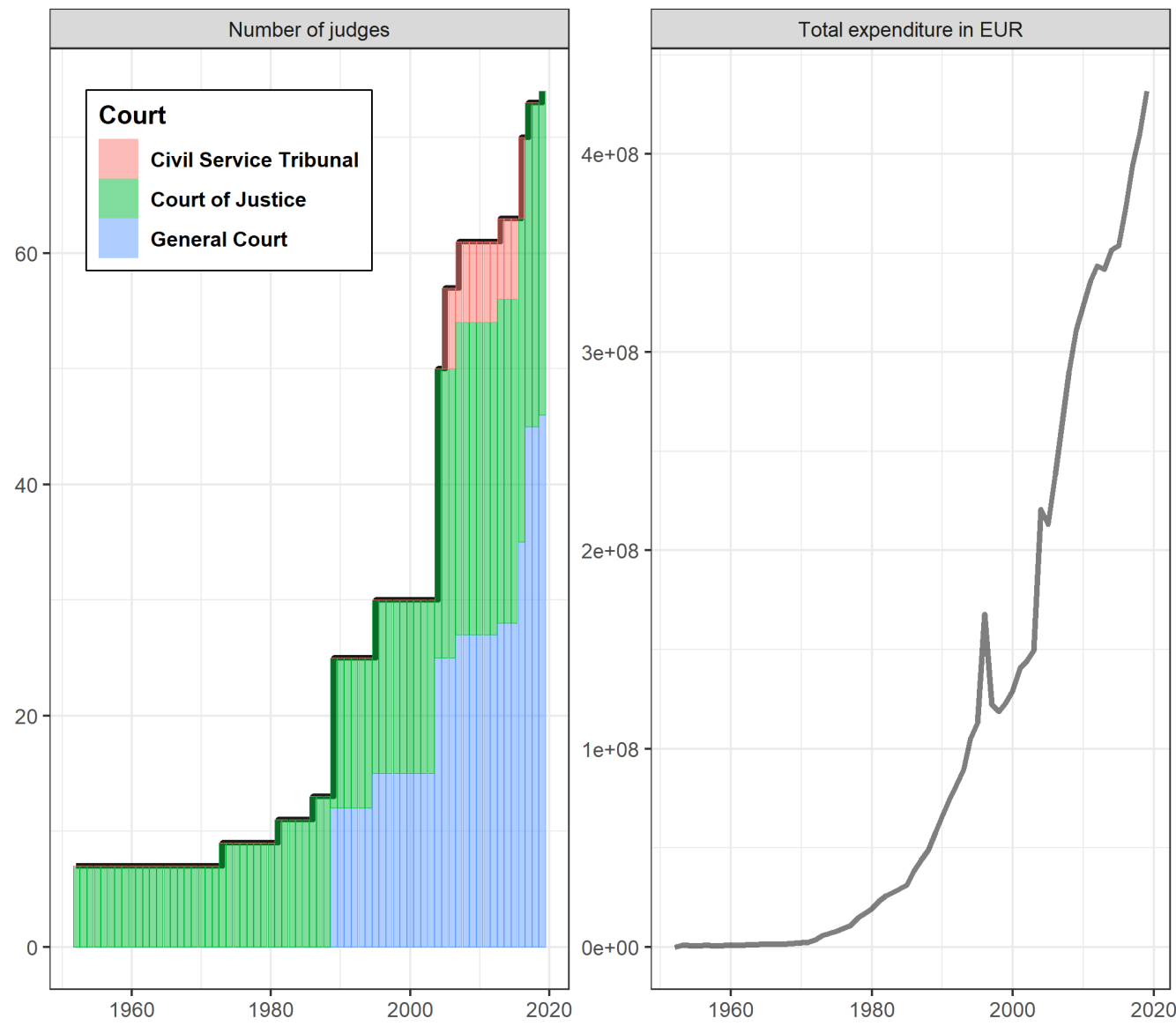

Figure 7: Number of judges and total expenditure in EUR of the CJEU by year (1952-2019).

Note: Prior to the introduction of the euro the amounts were expressed in terms of the European Currency Unit (ECU).

In the effective sample used for estimation we constrain the time period to 1954-2017 (by submission year), as many cases submitted in 2018 and 2019 have not yet been decided. We also exclude cases removed from the docket, as this type of decision is usually imposed exogenously by virtue of the parties or the national court discontinuing proceedings. ${ }^{13}$ On the one hand, removals are extremely short as a result - merely acknowledging the withdrawal of the case - which does not accurately reflect the quality of decision-making. On the other hand, due to the exogenous nature of most removals, the cases can eat up quite a lot of time before being removed from the docket due to an unforeseeable decision of the litigants. Table 1 summarizes the main variables in the effective sample.

\footnotetext{
${ }^{13}$ We can also see in Figure 5 that the number of removals does not change as a linear function of the number of cases received, which indicates that the Court is not able to exploit this decision type as a strategic instrument of case efficiency.
} 
Table 1: Summary statistics of main variables (1954-2017)

\begin{tabular}{lcccc}
\hline Statistic & Mean & St. Dev. & Min & Max \\
\hline Quality & 7.801 & 1.227 & 1.294 & 12.072 \\
Speed & -6.125 & 0.885 & -8.637 & 0 \\
Backlog (ln) & 3.702 & 0.473 & 0 & 4.732 \\
Expenditure (ln) & 15.144 & 0.631 & 11.353 & 15.544 \\
Digits per word (ln) & -2.334 & 0.861 & -4.596 & 2.473 \\
Year & 2000.889 & 12.449 & 1954 & 2017 \\
Court: CST & 0.052 & 0.221 & 0 & 1 \\
Court: GC & 0.343 & 0.475 & 0 & 1 \\
Appeal & 0.095 & 0.293 & 0 & 1 \\
Competition & 0.116 & 0.320 & 0 & 1 \\
Decision: Judgement & 0.601 & 0.490 & 0 & 1 \\
Procedure: Annulment & 0.296 & 0.456 & 0 & 1 \\
Procedure: Infringement & 0.085 & 0.280 & 0 & 1 \\
Procedure: Preliminary & 0.318 & 0.466 & 0 & 1 \\
Procedure: Staff & 0.157 & 0.364 & 0 & 1 \\
Procedure: Other & 0.052 & 0.222 & 0 & 1 \\
Procedure: Unknown & 0.092 & 0.288 & 0 & 1 \\
\hline No. of Observations: 28,301 & & & \\
\hline
\end{tabular}

Note: All variables are measured at the case level with the exception of expenditure and number of judges which are at the year level.

\section{$5 \quad$ Empirical Strategy and Results}

In order to rigorously assess the effect of backlog and resources on quality of output and judicial speed, we propose a set of empirical strategies. Below we outline each econometric specification along with the empirical results. The model predicts that a larger capacity in resources leads to improvements in both quality and speed, while an increasing backlog exerts the opposite effect on both.

Before moving to hypothesis testing we verify the necessary condition $C_{1}$. The condition presumes that quality and speed are negatively correlated and it is a central feature of our theoretical model. We theoretically posited that judiciaries face a trade-off between producing fast and high quality decisions. Figure 8 shows that the hypothesized trade-off has strong empirical support in the data and corroborates our necessary condition. 


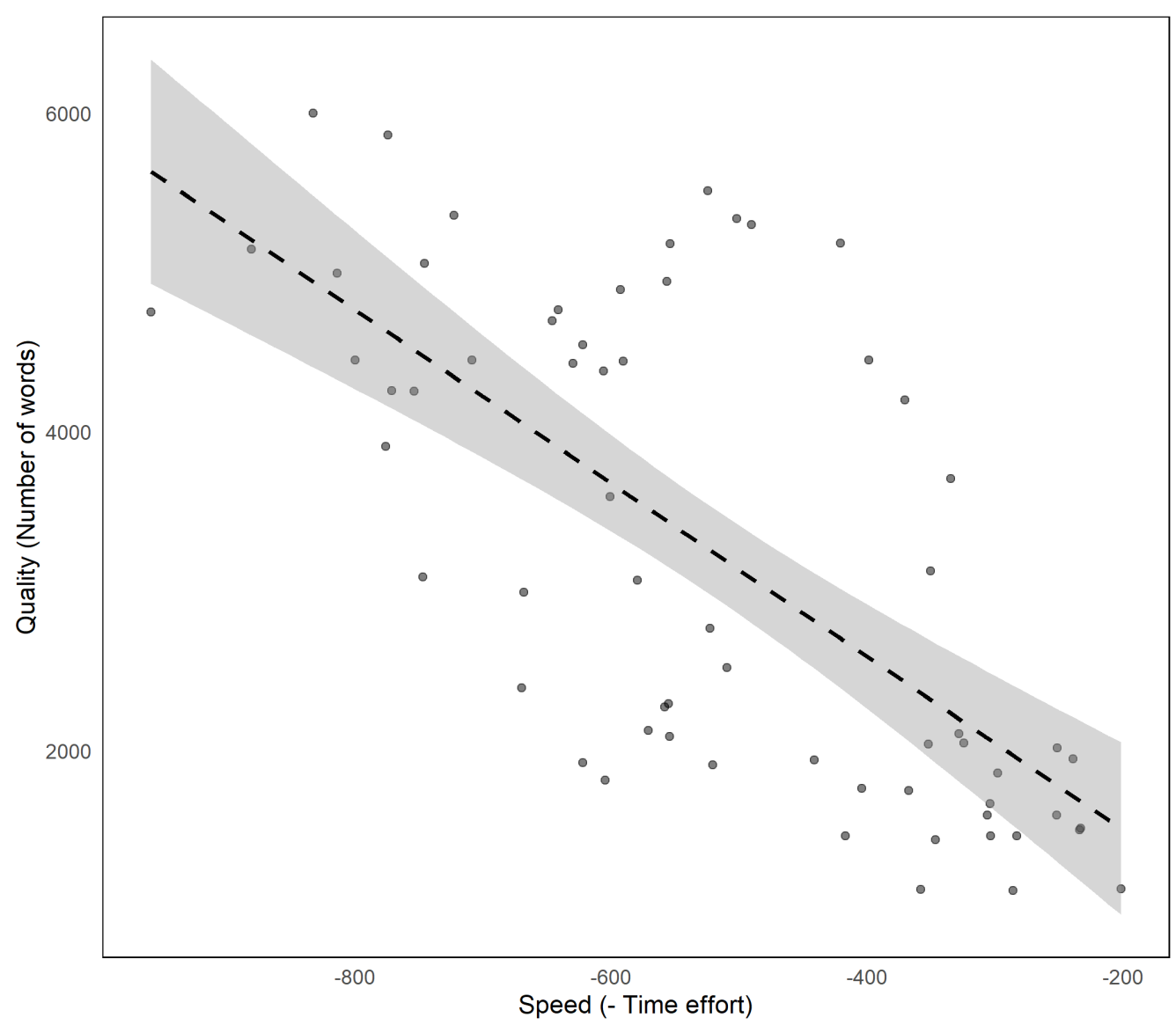

Figure 8: Trade-off between quality and speed at the Court of Justice of the European Union.

Note: Speed is measured as the minus of time effort, while quality is measured as the number of words. Each point represents average yearly values.

\subsection{Baseline: OLS}

We now turn to testing our hypotheses, namely that backlogs have a negative effect on decision-making quality and speed $\left(H_{1}\right)$, while resources have a positive effect $\left(H_{2}\right)$. We proxy the quality of decisions by the count of words and judicial speed by the minus of the amount of days required to reach a decision. We compute the court-specific backlog on the date of each decision by counting all outstanding cases, and then divide them equally to judges of each court. By doing this, we roughly measure the backlog pressure on judges. Ignoring the simultaneous bias for the moment, we regress the following equations:

$$
\text { speed }=-\ln (\text { duration })=\beta_{0}+\beta_{1} \text { quality }+\beta_{2} \ln (\text { backlog })+\beta_{3} \ln (\text { resources })+\boldsymbol{x}^{\prime} \boldsymbol{\phi}+v
$$

and

$$
\text { quality }=\ln (\text { words })=\eta_{0}+\eta_{1} \text { speed }+\eta_{2} \ln (\text { backlog })+\eta_{3} \ln (\text { resources })+\boldsymbol{x}^{\prime} \boldsymbol{\tau}+\epsilon
$$


where $\boldsymbol{x}$ is a vector that includes all other control variables, $\boldsymbol{\tau}$ and $\boldsymbol{\phi}$ are vectors consisting of corresponding coefficients, and $v$ and $\epsilon$ are two random error terms with zero means. The idea behind regression (10) is that, holding speed and other factors constant, an outward (inward) shift of the resource constraint would very likely improve (reduce) quality. The same logic applies to regression (11).

Control variables include (log) total expenditure per judge (not court-specific) and (log) digits per word. The former captures the resources available to a judge and the latter the complexity of a case. Moreover, we identify the court handling each case, whether it is an appeal case, whether the decision is a judgement (as opposed to an order), whether it concerns competition issues, and the procedure of the case.

As depicted in Figure 7 and 6, our independent variables manifest a clear upward trend. We thus include a linear time-trend in the regression. Additionally, we cluster standard errors at the year level to deal with any issues related to serial correlation.

Table 2 reports the OLS results. Refer to Column (1) and (2): speed and quality are negatively correlated. As expected backlog is negatively correlated with speed and quality. Complexity, measured by digits per word, has a negative relationship with both speed and quality. Expenditure per judge, however, does not robustly correlate with speed, but has the expected sign. Columns (3) and (4) in addition control for court fixed effects (the reference group is the Court of Justice), whether the case is an appeal case, whether the decision is a judgement, whether the case concerns competition issues, and procedure fixed effects. Adding these fixed effects does not alter the results substantially but improves moderately the goodness of fit. 
Table 2: Backlog on Quality and Speed: OLS

\begin{tabular}{|c|c|c|c|c|}
\hline & $\begin{array}{c}(1) \\
\text { Speed }\end{array}$ & $\begin{array}{c}\text { (2) } \\
\text { Quality }\end{array}$ & $\begin{array}{c}(3) \\
\text { Speed }\end{array}$ & $\begin{array}{c}\text { (4) } \\
\text { Quality }\end{array}$ \\
\hline Quality & $\begin{array}{c}-0.3251^{* * *} \\
(0.0306)\end{array}$ & & $\begin{array}{c}-0.2249^{* * *} \\
(0.0198)\end{array}$ & \\
\hline Backlog & $\begin{array}{c}-0.4825^{* * *} \\
(0.0941)\end{array}$ & $\begin{array}{c}-0.3500^{* * *} \\
(0.1137)\end{array}$ & $\begin{array}{c}-0.5855^{* * *} \\
(0.0938)\end{array}$ & $\begin{array}{c}-0.2445^{* *} \\
(0.0994)\end{array}$ \\
\hline Expenditure & $\begin{array}{c}0.0926 \\
(0.1258)\end{array}$ & $\begin{array}{c}0.3406^{* *} \\
(0.1421)\end{array}$ & $\begin{array}{c}0.2314^{* *} \\
(0.1156)\end{array}$ & $\begin{array}{c}0.2623^{* *} \\
(0.1272)\end{array}$ \\
\hline Digits & $\begin{array}{c}-0.4052^{* * *} \\
(0.0289)\end{array}$ & $\begin{array}{c}-0.9123^{* * *} \\
(0.0352)\end{array}$ & $\begin{array}{c}-0.4746^{* * *} \\
(0.0309)\end{array}$ & $\begin{array}{c}-0.8414^{* * *} \\
(0.0428)\end{array}$ \\
\hline Trend & $\begin{array}{c}0.0023 \\
(0.0062)\end{array}$ & $\begin{array}{c}0.0027 \\
(0.0067)\end{array}$ & $\begin{array}{l}-0.0089 \\
(0.0054)\end{array}$ & $\begin{array}{c}0.0049 \\
(0.0060)\end{array}$ \\
\hline Speed & & $\begin{array}{c}-0.3978^{* * *} \\
(0.0221)\end{array}$ & & $\begin{array}{c}-0.3273^{* * *} \\
(0.0281)\end{array}$ \\
\hline Appeal & & & $\begin{array}{c}0.1047^{* * *} \\
(0.0363)\end{array}$ & $\begin{array}{c}0.1434^{* *} \\
(0.0623)\end{array}$ \\
\hline Competition & & & $\begin{array}{c}-0.1640^{* * *} \\
(0.0329)\end{array}$ & $\begin{array}{c}0.4468^{* * *} \\
(0.0702)\end{array}$ \\
\hline Judgement & & & $\begin{array}{c}-0.6657^{* * *} \\
(0.0359)\end{array}$ & $\begin{array}{c}0.2349^{* * *} \\
(0.0626)\end{array}$ \\
\hline Court FE & No & No & Yes & Yes \\
\hline Procedure FE & No & No & Yes & Yes \\
\hline$N$ & 28301 & 28301 & 28301 & 28301 \\
\hline$R^{2}$ & 0.1931 & 0.4868 & 0.3545 & 0.5116 \\
\hline
\end{tabular}

Standard errors clustered at year level are given in parentheses

${ }^{*} p<.1,{ }^{* *} p<.05,{ }^{* * *} p<.01$

\subsection{Instrumental-Variable Estimation}

The results from the baseline OLS regression are likely to be erroneous and biased as OLS neglects the simultaneous determination of quality and speed. The simultaneous equation bias stems from the fact that the dependent variables are jointly determined by the equations (10 and 11) in the system causing that quality and $v$, and speed and $\epsilon$ are correlated. To solve this simultaneous equation bias, we apply instrumental-variable approach (hereafter IV estimation).

The exclusion restriction criterion requires that the chosen instrument is only affecting the outcome variable through the endogenous explanatory variable. We use the lagged value of the yearly (decision-procedure-specific) average speed of resolving a case as an instrument for judicial speed. Our instrumental variable captures the intangible pressure judges face in living up to past usual standard or benchmark (average speed). Virtually 
all courts maintain at minimum internal benchmarks for speed, juxtaposing expected performance against past performance (in terms of speed) in similar cases. ${ }^{14}$ This was explicitly confirmed in the CJEU context by a review of the European Court of Auditors (European Court of Auditors, 2017). As a result, we can proxy speed standards set by past performance - much in the same way courts do in practice - by looking at lagged average speed. While speed benchmarks affect case duration directly - judges are pressurized to comply with standardized deadlines by a set of positive and negative incentives (European Court of Auditors, 2017) - any effect of average speed on quality is indirect and mediated through actual speed. Because speed benchmarks rarely have counterparts in the domain of quality, the latter is only impacted indirectly as a by-product of judges straining to match past speed standards. Moreover, as most cases are independent, the speed benchmark should not have any impact on the quality of the current case at hand.

We estimate the first and second stage equation using court and procedure fixed effects and control variables.

Equations 10 and 11 can be rewritten as:

$$
\text { speed }=\beta_{0}+\beta_{1} \text { benchmark }+\beta_{2} \ln (\text { backlog })+\beta_{3} \ln (\text { resources })+\boldsymbol{x}^{\prime} \boldsymbol{\phi}+v
$$

and

$$
\text { quality }=\eta_{0}+\eta_{1} \widehat{\text { speed }}+\eta_{2} \ln (\text { backlog })+\eta_{3} \ln (\text { resources })+\boldsymbol{x}^{\prime} \boldsymbol{\tau}+\epsilon
$$

By instrumentalizing judicial speed with a speed benchmark, we are able to identify the quality equation and obtain unbiased estimates of $\eta_{1}, \eta_{2}$ and $\eta_{3}$. The former will tell us the slope of the trade-off between quality and speed. The inverse of it is interpreted as the relative price of quality, i.e. the larger the absolute value of $\eta_{1}$ the lower the price as $\eta_{1}$ is supposed to be negative. $\eta_{2}$ and $\eta_{3}$ represent the short term impact of backlog and resources on quality, holding speed constant.

Table 3 reports the IV estimation results. Column (1) and (2) are the second and first stages of the IV estimation respectively, where judgment, court and procedure fixed effects are not controlled for. First of all, speed is inversely correlated with quality, consistent with our theoretical model. Coinciding with our theoretical predictions, backlog has a negative impact on quality and expenditure has a positive impact. The instrumental variable is significant and the F-test of excluded instruments indicates that it is sufficiently strong. Column

\footnotetext{
${ }^{14}$ On the contrary, few if any courts measure the quality of judicial output, not least due to the measurement difficulties and sensitivity among judges it raises.
} 
(3) and (4) further control for judgement, court and procedure fixed effects. The $R^{2}$ of the first stage increases substantially, while the lagged average speed is still significant. A notable change is the sign of the impact of backlog on speed becomes significant. The negative relationship between speed and quality is significant and the magnitude is even larger. A one percent increase in speed is on average correlated with 0.76 percent fall in quality, which is larger than the OLS estimate.

Table 3: Backlog on Speed: IV and Reduced-form Estimation

\begin{tabular}{|c|c|c|c|c|c|c|}
\hline & $\begin{array}{c}\text { (1) } \\
\text { IV-2nd }\end{array}$ & $\begin{array}{c}\text { (2) } \\
\text { IV-1st } \\
\text { Speed }\end{array}$ & $\begin{array}{c}(3) \\
\text { IV-2nd } \\
\text { Ouplity }\end{array}$ & $\begin{array}{c}(4) \\
\text { IV-1st } \\
\text { Sneed }\end{array}$ & $\begin{array}{c}(5) \\
\text { Reduced }\end{array}$ & $\begin{array}{c}\text { (6) } \\
\text { Reduced }\end{array}$ \\
\hline Dep. Variable & & & & & & \\
\hline Speed & $\begin{array}{c}-0.6463^{* * *} \\
(0.0644)\end{array}$ & & $\begin{array}{c}-0.7649^{* * *} \\
(0.1015)\end{array}$ & & & \\
\hline Benchmark & & $\begin{array}{c}0.8730^{* * *} \\
(0.0608)\end{array}$ & & $\begin{array}{c}0.5937^{* * *} \\
(0.0432)\end{array}$ & $\begin{array}{c}-0.5693^{* * *} \\
(0.0578)\end{array}$ & $\begin{array}{c}-0.4541^{* * *} \\
(0.0543)\end{array}$ \\
\hline Backlog & $\begin{array}{c}-0.4642^{* * *} \\
(0.1093)\end{array}$ & $\begin{array}{l}-0.0111 \\
(0.1263)\end{array}$ & $\begin{array}{c}-0.4985^{* * *} \\
(0.1289)\end{array}$ & $\begin{array}{c}-0.3895^{* * *} \\
(0.1048)\end{array}$ & $\begin{array}{c}-0.2873^{* * *} \\
(0.1044)\end{array}$ & $\begin{array}{l}-0.2006^{*} \\
(0.1071)\end{array}$ \\
\hline Expenditure & $\begin{array}{l}0.3555^{* *} \\
(0.1570)\end{array}$ & $\begin{array}{l}-0.0804 \\
(0.1208)\end{array}$ & $\begin{array}{l}0.3642^{* *} \\
(0.1514)\end{array}$ & $\begin{array}{l}0.2122^{* *} \\
(0.1020)\end{array}$ & $\begin{array}{l}0.2418^{*} \\
(0.1402)\end{array}$ & $\begin{array}{c}0.2019 \\
(0.1394)\end{array}$ \\
\hline Digits & $\begin{array}{c}-0.9434^{* * *} \\
(0.0386)\end{array}$ & $\begin{array}{l}-0.0295 \\
(0.0250)\end{array}$ & $\begin{array}{c}-0.9824^{* * *} \\
(0.0611)\end{array}$ & $\begin{array}{c}-0.1766^{* * *} \\
(0.0270)\end{array}$ & $\begin{array}{c}-0.9182^{* * *} \\
(0.0424)\end{array}$ & $\begin{array}{c}-0.8473^{* * *} \\
(0.0549)\end{array}$ \\
\hline Trend & $\begin{array}{c}0.0022 \\
(0.0075)\end{array}$ & $\begin{array}{l}0.0090^{*} \\
(0.0048)\end{array}$ & $\begin{array}{l}-0.0005 \\
(0.0075)\end{array}$ & $\begin{array}{c}-0.0087^{* *} \\
(0.0039)\end{array}$ & $\begin{array}{c}0.0041 \\
(0.0065)\end{array}$ & $\begin{array}{c}0.0062 \\
(0.0063)\end{array}$ \\
\hline Appeal & $\begin{array}{c}0.1247^{* * *} \\
(0.0436)\end{array}$ & $\begin{array}{l}-0.0217 \\
(0.0329)\end{array}$ & $\begin{array}{c}0.1896^{* * *} \\
(0.0551)\end{array}$ & $\begin{array}{c}0.0062 \\
(0.0512)\end{array}$ & $\begin{array}{l}0.0922^{*} \\
(0.0489)\end{array}$ & $\begin{array}{c}0.1848^{* * *} \\
(0.0680)\end{array}$ \\
\hline Competition & $\begin{array}{c}0.2997^{* * *} \\
(0.0517)\end{array}$ & $\begin{array}{c}-0.2111^{* * *} \\
(0.0332)\end{array}$ & $\begin{array}{c}0.3284^{* * *} \\
(0.0640)\end{array}$ & $\begin{array}{c}-0.2051^{* * *} \\
(0.0304)\end{array}$ & $\begin{array}{c}0.4629^{* * *} \\
(0.0563)\end{array}$ & $\begin{array}{c}0.4853^{* * *} \\
(0.0778)\end{array}$ \\
\hline Judgement & & & $\begin{array}{l}-0.0933 \\
(0.0990)\end{array}$ & $\begin{array}{c}-0.4467^{* * *} \\
(0.0342)\end{array}$ & & $\begin{array}{c}0.2483^{* * *} \\
(0.0673)\end{array}$ \\
\hline Court FE & No & No & Yes & Yes & No & Yes \\
\hline Procedure FE & No & No & Yes & Yes & No & Yes \\
\hline$N$ & 27254 & 27254 & 27254 & 27254 & 27254 & 27254 \\
\hline$R^{2}$ & 0.4258 & 0.2962 & 0.4035 & 0.3832 & 0.4455 & 0.4613 \\
\hline F-test of Excluded Instruments & & 206 & & 189 & & \\
\hline
\end{tabular}

Standard errors clustered at year level are given in parentheses

${ }^{*} p<.1,{ }^{* *} p<.05,{ }^{* * *} p<.01$

\subsection{Reduced-Form Estimation}

While we are not only interested in the trade-off ratio between quality and speed, we seek to examine the long-term impact of backlog/resources by regressing the reduced-form equations. This serves the purpose of understanding the equilibrium impact of backlog/resources on both dependent variables. We solve for equilibrium 
quality and speed as functions of the exogenous variables and obtain the following reduced-form equations:

$$
\text { speed }=\gamma_{0}+\gamma_{1} \ln (\text { backlog })+\gamma_{2} \ln (\text { resources })+\gamma_{3} \text { benchmark }+\boldsymbol{x}^{\prime} \boldsymbol{\psi}+\omega
$$

and

$$
\text { quality }=\mu_{0}+\mu_{1} \ln (\text { backlog })+\mu_{2} \ln (\text { resources })+\mu_{3} \text { benchmark }+\boldsymbol{x}^{\prime} \boldsymbol{\kappa}+\rho
$$

where the reduced-form coefficients are linear combinations of those coefficients of the structural model, and $\omega$ and $\rho$ are random error terms with mean zero. Both equations can be estimated by OLS and the coefficients are unbiased given that the model includes all relevant variables. The estimates are the equilibrium impacts of the independent variables on the dependent variable, taking into account the equilibrium interaction between quality and speed. Equation 14 is actually the first-stage estimation of the IV estimation discussed above.

The comparison between the IV and the reduced-form estimates allows us to better understand the relationship between variables through the mechanism of the theoretical model. The reduced-form results should be interpreted as the equilibrium adjustments or the long-term effects, while the IV estimation gives unbiased estimates of the short-term impact of each independent variable on the dependent variable while holding all other factors constant.

Column (2), (4), (5) and (6) of Table 3 report the reduced-form results. As court and procedures fixed effects improve substantially the goodness of fit, we focus on the fully-specified model. Refer to Column (4) and (6): backlog has a negative impact on speed and a negative marginally significant impact on quality. The magnitude of the effect on quality $(-0.2006)$ is smaller than the IV estimate $(-0.4985)$, showing the adjustment of speed along the new budget constraint that mitigates the fall in quality. Figure 9 illustrates the comparison between IV and reduced-form estimates. An increase in backlog shifts the budget constraint inward, leading to a new equilibrium pair of speed and quality $\left(S^{R F}, Q^{R F}\right)$. The IV estimate of change in quality $\left(Q^{I V}-Q_{1}\right)$ is larger as it has not taken into account the equilibrium adjustment in speed. Expenditures is positive but statistically not significant in column (6) indicating that there is no solid positive impact of rising the available resources. Similar to backlog, the magnitude of expenditures in the reduced form equation is slightly smaller (0.2019) than the IV estimate (0.3642). Our finding does not present a strong support for the second hypothesis $\left(H_{2}\right)$. 


\section{Quality (Q)}

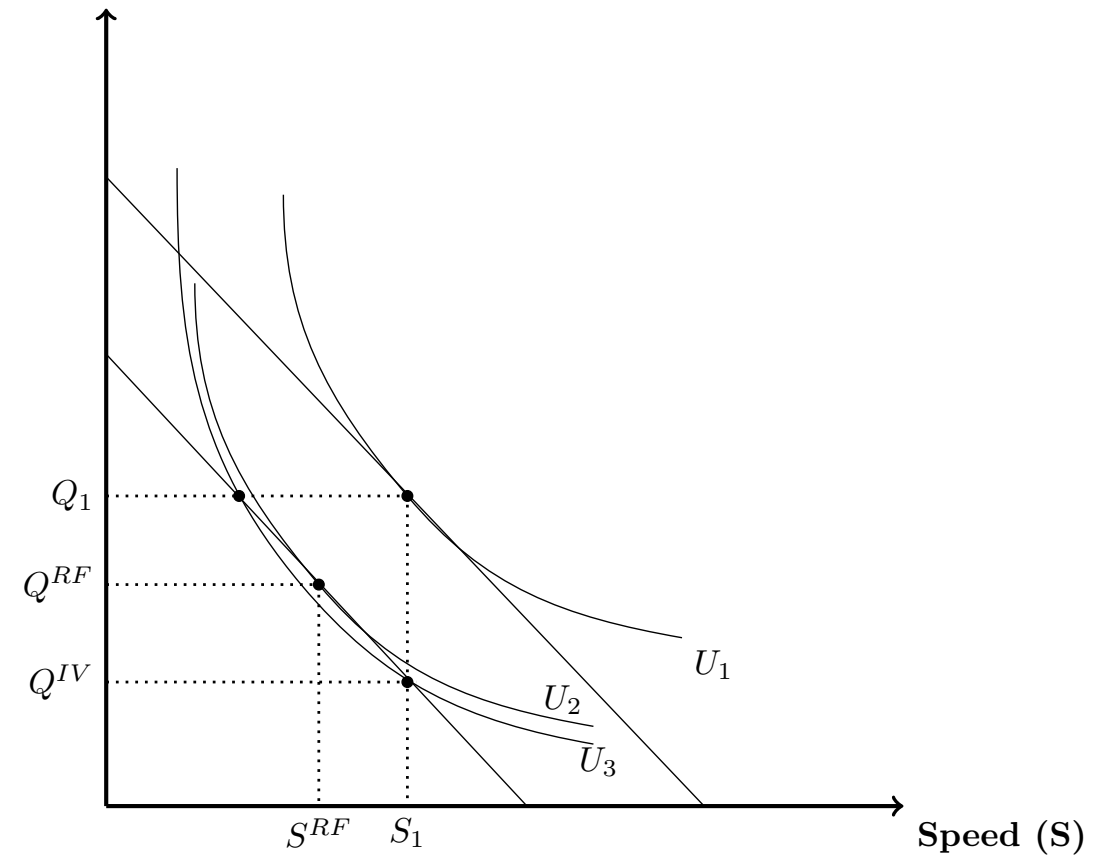

Figure 9: An increase in backlog shifts the budget constraint inward.

Note: An increase in backlog shifts the budget constraint inward. The new quality-speed equilibrium is the pair $\left(S^{R F}, Q^{R F}\right)$, which is obtained through the reduced-form equation. The IV estimation produces an unbiased effect of shifting the budget constraint but does not consider the equilibrium adjustment. The OLS estimates are biased.

\subsection{Court reforms}

As outlined in Section 3, the CJEU has undergone several major and minor reforms over the years. Two reforms (pre-2016) stand-out in particular: introduction of the General Court in 1989 ("first reform") and introduction of the Civil Service Tribunal in 2005 ("second reform"). Figure 10 portrays the evolution of average case duration with trends cut at the moment in which the two reforms took place (1989 and 2005). We can see that the policy interventions were roughly successful in reducing the length of proceedings. The first intervention was targeted at alleviating some of the case burden on the Court of Justice; the main beneficiary of the second reform was the General Court. 


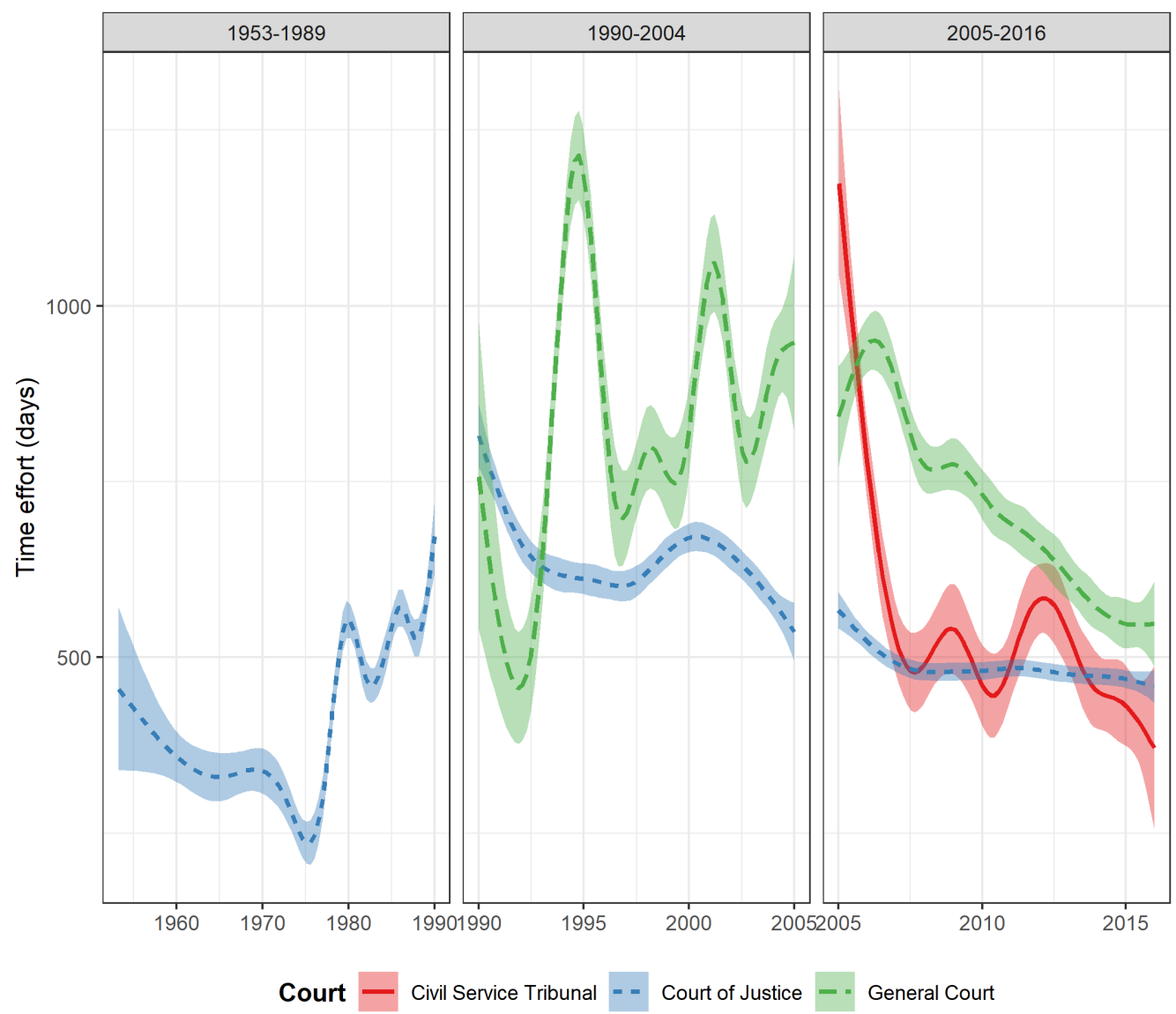

Figure 10: Comparison of Time Effort (negative of speed) of three Courts

Note: Time effort (Duration) is measured in days from case submission to final decision. 


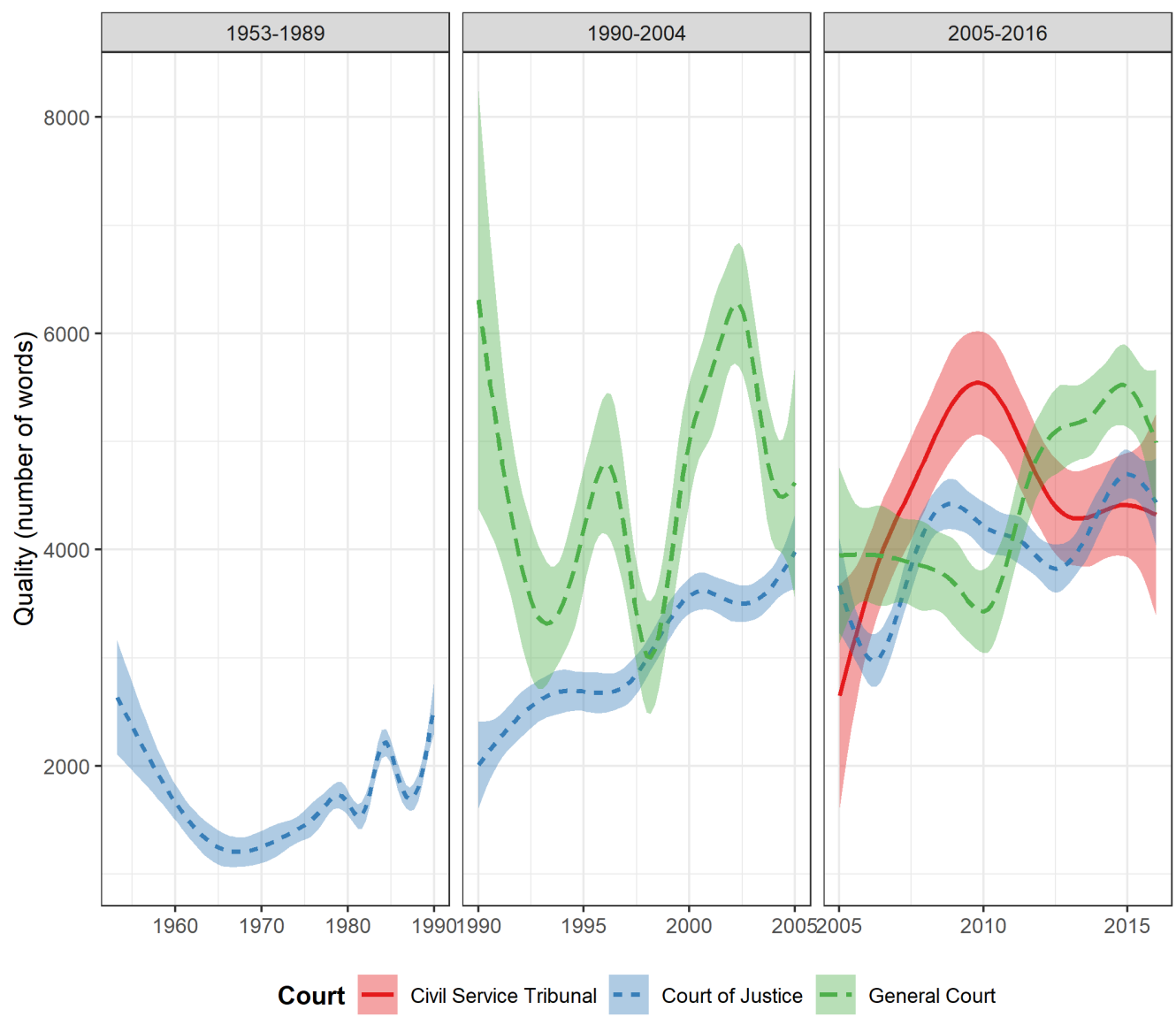

Figure 11: Comparison of Quality of three Courts

Note: Quality is measured as the number of words in a decision.

Moreover, the creation of the General Court in 1989 had a positive effect on the quality of decisions produced by the Court of Justice (see Figure 11), seemingly vindicating the hopes of some observers (Slynn, 1989) more than the skepticism of others (Jacqué and Weiler, 1990). The same can be said about the creation of the specialized Civil Service Tribunal, which took over responsibility for staff cases in 2005, with respect to the General Court.

These assessments are superficial, however. In order to truly understand the effect of the court reforms, we need to take into account a broader range of factors than the dependent variables themselves. In this section we attempt to rigorously test - to our knowledge for the first time in the EU context - if the establishment of new courts helped improve speed and quality given the dynamic nature of complementary factors such as backlog and resources.

We further develop our econometric model to accommodate the fact that reforms were due to an excessive backlog and that the impact of reforms on speed is mainly reflected by the reduction in backlog. In other words, backlog is endogenously determined and reforms are a possible instrumental variable. Keeping in mind 
that both backlog and quality are endogenous, we leverage the reduced-form estimation to study the long-term impact of the reforms on speed. To understand the impact of the introduction of the General Court in 1989 on the performance of the Court of Justice, we limit the sample to the Court of Justice and study if the new court -modelled as a potential change in the linear time trend- would impact the speed. By comparing before- and after-reform periods, we attempt to show the improvement in speed reflected by a different slope of the time trend. We follow similar steps to identify the impact of the introduction of the Civil Service Tribunal in 2005 on the performance of the General Court. Formally, we estimate the following equations:

$$
\text { speed }=\pi_{0}+\pi_{1} \text { reform }+\pi_{3} \text { trend }+\pi_{3} \text { reform } \times \text { trend }+\pi_{4} \text { benchmark }+\pi_{5} \ln (\text { resources })+\boldsymbol{x}^{\prime} \boldsymbol{\lambda}+\xi
$$

and

$$
\text { quality }=\sigma_{0}+\sigma_{1} \text { reform }+\sigma_{2} \text { trend }+\sigma_{3} \text { reform } \times \text { trend }+\sigma_{4} \text { benchmark }+\sigma_{5} \ln (\text { resources })+\boldsymbol{x}^{\prime} \boldsymbol{\delta}+\iota
$$

where trend has been centered at the year of the first reform, reform is a binary indicator of the period after the reform, $\xi$ and $\iota$ are random errors with zero mean, and $\boldsymbol{\lambda}$ and $\boldsymbol{\delta}$ are vectors of coefficients. We drop procedure fixed effects as some procedures - notably preliminary references - are only managed by a single court. We also take into account that the new court was typically assigned a particular type of cases or procedures (staff cases in both reforms, for example). The estimation would therefore be wrong if we grouped all procedures together. For this reason, we drop those procedures (annulments, staff and others for the first reform and staff cases for the second reform) that could have been taken up by the new court, so that the estimate is the impact of the reform on all other types of cases. This approach has two advantages. First, we avoid the problem that the estimated difference in the average performance would be simply due to a shift of burden. For example, we know for a fact that dozens of difficult competition cases were shifted from the Court of Justice to the General Court in the early 1990s, which would in itself precipitate a drop in the average delay at the former court. Second, by excluding overlapping procedures we are able to estimate the potential benefit of division of labour due to the reforms.

Table 4 shows the results concerning the introduction of the General Court in 1989. Refer to Column (1): 
we first limit the sample to the period 1974-2003, i.e. 15 years before and 15 years after the reform. We find some positive impact of the reform on speed over time (long-run) but not right at the beginning (short-run). We further limit the sample to the period 1979-1998 in column (2), i.e. 10 years before and 10 years after, and find that the reform has no significant impact on speed in the long-run. Column (3) limits the sample to period 1984-1993, i.e. 5 years before and 5 years after. No positive effect of the reform is found. In short, there is no robust evidence supporting the conclusion that the creation of the General Court had a positive impact on speed of the Court of Justice.

As regards quality, we find a positive long-run effect of the reform across all three samples of different periods. Taking the estimates of Column (5), we compute the predicted values of quality of the two scenarios with and without the reform. As illustrated in Figure 12, the average quality would have dropped by 37.6 percent in 5 years had no reform been carried out.

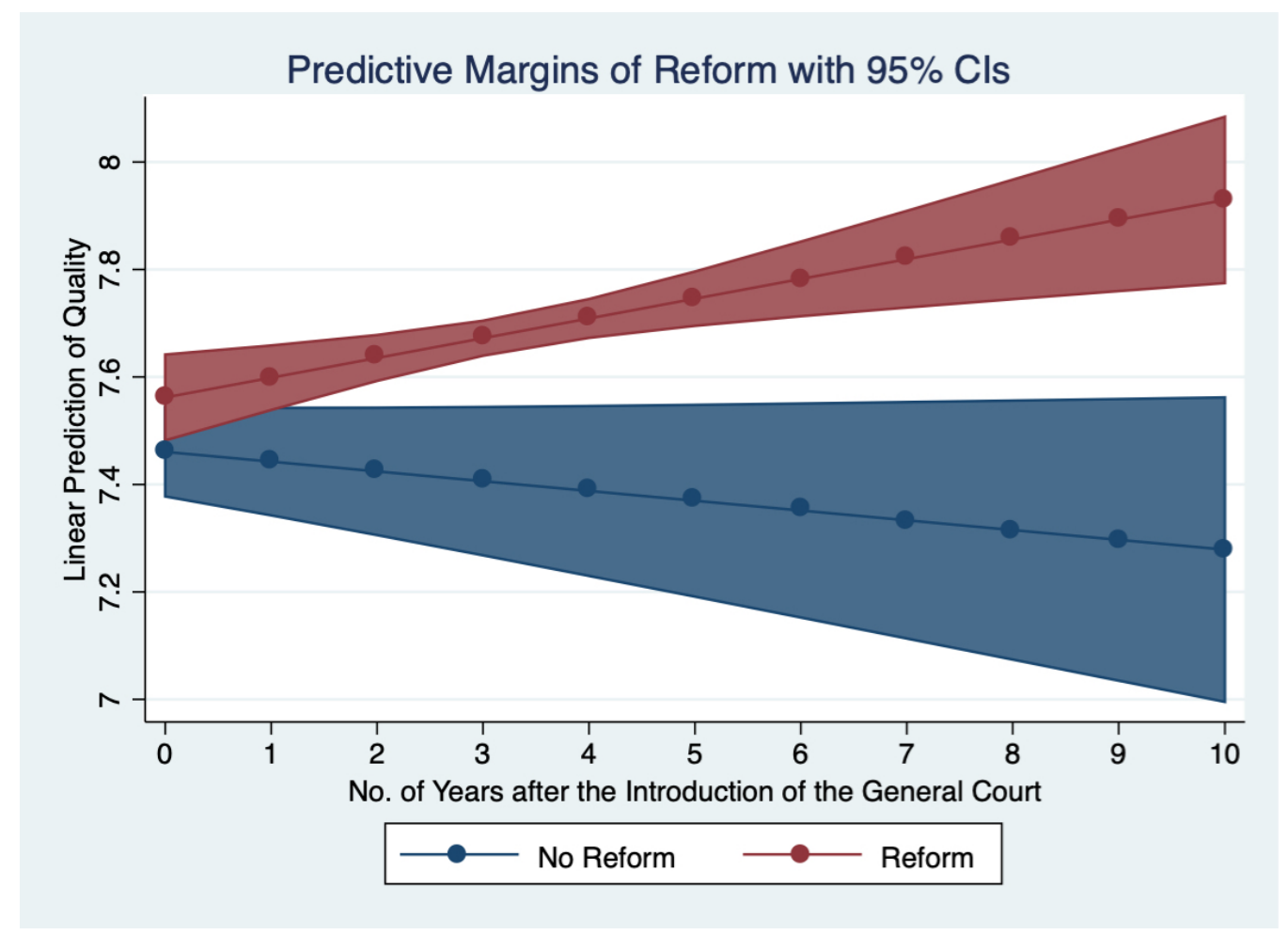

Figure 12: Impact of the Establishment of the General Court in 1989 on CJEU Decision Quality

Note: Without a reform in 1989, the average quality of decisions would have dropped by 37.6 percent in 5 years.

Table 5 shows the impact of the introduction of the Civil Service Tribunal in 2005. We do not find robust evidence supporting a positive impact on speed, but some evidence of a long-run effect on quality. In sum, we 
find that the two major reforms prior to the 2016 overhaul - for whose evaluation there is not yet enough data had a positive impact on the quality of decisions but not on speed. This is an interesting finding given that the stated policy concerns that prompted both reforms related predominantly to increasing decision-making speed.

Table 4: Introduction of General Court

\begin{tabular}{|c|c|c|c|c|c|c|}
\hline \multirow[b]{2}{*}{ Dep. variable } & (1) & $(2)$ & (3) & (4) & (5) & (6) \\
\hline & & Speed & & \multicolumn{3}{|c|}{ Quality } \\
\hline Period & $1974-2003$ & 1979-1998 & 1984-1993 & $1974-2003$ & 1979-1998 & 1984-1993 \\
\hline Benchmark & $\begin{array}{c}0.5524^{* * *} \\
(0.1019)\end{array}$ & $\begin{array}{c}0.5302^{* * *} \\
(0.1181)\end{array}$ & $\begin{array}{c}0.5714^{* * *} \\
(0.1636)\end{array}$ & $\begin{array}{c}-0.2780^{* * *} \\
(0.0694)\end{array}$ & $\begin{array}{c}-0.2185^{* * *} \\
(0.0634)\end{array}$ & $\begin{array}{l}-0.0627 \\
(0.0690)\end{array}$ \\
\hline Reform & $\begin{array}{c}0.0956 \\
(0.0937)\end{array}$ & $\begin{array}{l}0.1864^{* *} \\
(0.0842)\end{array}$ & $\begin{array}{l}-0.1772 \\
(0.3777)\end{array}$ & $\begin{array}{c}0.0730 \\
(0.0555)\end{array}$ & $\begin{array}{c}0.1012 \\
(0.0664)\end{array}$ & $\begin{array}{c}0.4658 \\
(0.2909)\end{array}$ \\
\hline Trend & $\begin{array}{c}-0.0350^{*} \\
(0.0187)\end{array}$ & $\begin{array}{c}-0.0445^{* *} \\
(0.0161)\end{array}$ & $\begin{array}{c}0.0374 \\
(0.0597)\end{array}$ & $\begin{array}{c}-0.0171^{*} \\
(0.0093)\end{array}$ & $\begin{array}{l}-0.0182^{*} \\
(0.0104)\end{array}$ & $\begin{array}{l}-0.1067^{*} \\
(0.0494)\end{array}$ \\
\hline Reform $\times$ Trend & $\begin{array}{c}0.0284^{* *} \\
(0.0132)\end{array}$ & $\begin{array}{c}0.0154 \\
(0.0127)\end{array}$ & $\begin{array}{l}-0.0145 \\
(0.0374)\end{array}$ & $\begin{array}{c}0.0574^{* * *} \\
(0.0065)\end{array}$ & $\begin{array}{c}0.0550^{* * *} \\
(0.0079)\end{array}$ & $\begin{array}{c}0.1143^{* * *} \\
(0.0152)\end{array}$ \\
\hline Digits & $\begin{array}{c}-0.0503^{* *} \\
(0.0183)\end{array}$ & $\begin{array}{c}-0.0554^{* *} \\
(0.0238)\end{array}$ & $\begin{array}{c}-0.1003^{*} \\
(0.0474)\end{array}$ & $\begin{array}{c}-0.7109^{* * *} \\
(0.0286)\end{array}$ & $\begin{array}{c}-0.7051^{* * *} \\
(0.0340)\end{array}$ & $\begin{array}{c}-0.6517^{* * *} \\
(0.0208)\end{array}$ \\
\hline Expenditure & $\begin{array}{c}0.0390 \\
(0.1385)\end{array}$ & $\begin{array}{l}0.2615^{* *} \\
(0.1059)\end{array}$ & $\begin{array}{l}-0.3124 \\
(0.8190)\end{array}$ & $\begin{array}{c}0.0069 \\
(0.0781)\end{array}$ & $\begin{array}{c}0.0101 \\
(0.1008)\end{array}$ & $\begin{array}{c}0.4281 \\
(0.5462)\end{array}$ \\
\hline Appeal & $\begin{array}{c}0.4653^{* * *} \\
(0.1077)\end{array}$ & $\begin{array}{c}0.1167 \\
(0.2628)\end{array}$ & $\begin{array}{c}0.3949 \\
(0.4795)\end{array}$ & $\begin{array}{c}-0.2609^{* * *} \\
(0.0789)\end{array}$ & $\begin{array}{l}-0.0948 \\
(0.1059)\end{array}$ & $\begin{array}{c}-0.1802^{* *} \\
(0.0562)\end{array}$ \\
\hline Competition & $\begin{array}{c}-0.1188^{* * *} \\
(0.0270)\end{array}$ & $\begin{array}{c}-0.1422^{* * *} \\
(0.0243)\end{array}$ & $\begin{array}{c}-0.1250^{* * *} \\
(0.0287)\end{array}$ & $\begin{array}{l}0.0973^{* *} \\
(0.0469)\end{array}$ & $\begin{array}{c}0.0851 \\
(0.0620)\end{array}$ & $\begin{array}{l}-0.0866 \\
(0.0832)\end{array}$ \\
\hline Judgement & $\begin{array}{c}-0.1815^{* * *} \\
(0.0430)\end{array}$ & $\begin{array}{c}-0.2166^{* * *} \\
(0.0621)\end{array}$ & $\begin{array}{c}-0.2610^{* *} \\
(0.0888)\end{array}$ & $\begin{array}{l}0.1436^{* *} \\
(0.0603)\end{array}$ & $\begin{array}{c}0.1520 \\
(0.0947)\end{array}$ & $\begin{array}{c}0.0510 \\
(0.0290)\end{array}$ \\
\hline Constant & $\begin{array}{l}-3.4455 \\
(2.3119)\end{array}$ & $\begin{array}{c}-6.9100^{* * *} \\
(1.9514)\end{array}$ & $\begin{array}{c}2.0764 \\
(13.1447)\end{array}$ & $\begin{array}{c}3.7832^{* * *} \\
(1.2194)\end{array}$ & $\begin{array}{l}4.1019^{* *} \\
(1.6611)\end{array}$ & $\begin{array}{l}-1.1970 \\
(8.4744)\end{array}$ \\
\hline$N$ & 5775 & 3807 & 1810 & 5775 & 3807 & 1810 \\
\hline$R^{2}$ & 0.3963 & 0.2825 & 0.2276 & 0.6026 & 0.6105 & 0.5630 \\
\hline
\end{tabular}

Standard errors clustered at year level are given in parentheses

${ }^{*} p<.1,{ }^{* *} p<.05,{ }^{* * *} p<.01$ 
Table 5: Introduction of Civil Service Tribunal

\begin{tabular}{|c|c|c|c|c|}
\hline \multirow{3}{*}{$\begin{array}{l}\text { Dep. variable } \\
\text { Period }\end{array}$} & (1) & $(2)$ & $(3)$ & (4) \\
\hline & \multicolumn{2}{|c|}{ Speed } & \multicolumn{2}{|c|}{ Quality } \\
\hline & 1994-2015 & $1999-2010$ & $1994-2015$ & $1999-2010$ \\
\hline Lag Speed & $\begin{array}{c}0.5532^{* * *} \\
(0.1207)\end{array}$ & $\begin{array}{c}0.3039^{* * *} \\
(0.0874)\end{array}$ & $\begin{array}{c}-1.4859^{* * *} \\
(0.2482)\end{array}$ & $\begin{array}{c}-1.5614^{* * *} \\
(0.2909)\end{array}$ \\
\hline Reform & $\begin{array}{c}0.4362^{* * *} \\
(0.1352)\end{array}$ & $\begin{array}{c}0.0293 \\
(0.1438)\end{array}$ & $\begin{array}{c}-1.5484^{* * *} \\
(0.3603)\end{array}$ & $\begin{array}{l}-0.1319 \\
(0.1315)\end{array}$ \\
\hline Trend & $\begin{array}{c}0.0003 \\
(0.0167)\end{array}$ & $\begin{array}{c}-0.0400^{* *} \\
(0.0144)\end{array}$ & $\begin{array}{l}-0.0140 \\
(0.0441)\end{array}$ & $\begin{array}{c}-0.1992^{* * *} \\
(0.0162)\end{array}$ \\
\hline Reform $\times$ Trend & $\begin{array}{c}-0.0621^{*} \\
(0.0337)\end{array}$ & $\begin{array}{c}0.1655^{* *} \\
(0.0519)\end{array}$ & $\begin{array}{c}0.2790^{* * *} \\
(0.0492)\end{array}$ & $\begin{array}{c}0.1494^{* *} \\
(0.0566)\end{array}$ \\
\hline Digits & $\begin{array}{c}-0.2571^{* * *} \\
(0.0696)\end{array}$ & $\begin{array}{c}-0.3189^{* * *} \\
(0.0797)\end{array}$ & $\begin{array}{c}-1.3150^{* * *} \\
(0.1607)\end{array}$ & $\begin{array}{c}-1.5830^{* * *} \\
(0.1994)\end{array}$ \\
\hline Expenditure & $\begin{array}{l}1.0039^{* *} \\
(0.4410)\end{array}$ & $\begin{array}{c}-0.9613^{* *} \\
(0.4218)\end{array}$ & $\begin{array}{c}-1.3452^{*} \\
(0.6891)\end{array}$ & $\begin{array}{c}1.2680^{* * *} \\
(0.3454)\end{array}$ \\
\hline Appeal & $\begin{array}{c}-0.4295^{* *} \\
(0.1819)\end{array}$ & $\begin{array}{c}-0.4430^{*} \\
(0.2011)\end{array}$ & $\begin{array}{c}0.1991 \\
(0.1241)\end{array}$ & $\begin{array}{c}0.1434 \\
(0.2078)\end{array}$ \\
\hline Competition & $\begin{array}{c}-0.2854^{* * *} \\
(0.0509)\end{array}$ & $\begin{array}{c}-0.3258^{* * *} \\
(0.0623)\end{array}$ & $\begin{array}{c}0.1771 \\
(0.1060)\end{array}$ & $\begin{array}{c}0.9442^{* * *} \\
(0.1301)\end{array}$ \\
\hline Judgement & $\begin{array}{c}-0.9029^{* * *} \\
(0.1014)\end{array}$ & $\begin{array}{c}-1.0697^{* * *} \\
(0.1132)\end{array}$ & $\begin{array}{c}-0.8321^{* * *} \\
(0.2262)\end{array}$ & $\begin{array}{c}-0.9001^{* *} \\
(0.2983)\end{array}$ \\
\hline Constant & $\begin{array}{c}-17.9818^{* *} \\
(6.5327)\end{array}$ & $\begin{array}{l}10.3700 \\
(6.1602)\end{array}$ & $\begin{array}{c}15.7743 \\
(10.3900)\end{array}$ & $\begin{array}{c}-25.7773^{* * *} \\
(5.1245)\end{array}$ \\
\hline$N$ & 4822 & 2665 & 4822 & 3562 \\
\hline$R^{2}$ & 0.3492 & 0.3579 & 0.4479 & 0.5334 \\
\hline
\end{tabular}

\section{Conclusion}

In this paper we developed and tested a new economic theory of court performance, inspired by foundations of neoclassical consumer theory. Judges make decisions over judicial quality and speed under a resource constraint. Contrary to what much of the literature suggests, our model predicts that increasing backlog is very likely to worsen both quality and speed. Using case-level data of the Court of Justice of the European Union and solving the simultaneous determination of quality and speed through an instrumental-variable approach, we find robust evidence that backlog adversely impacts the speed and quality of case resolution. The CJEU is seen as insisting on maintaining its levels of quality, measured by the length of each decision, though less resolutely since the turn of the millennium. In addition, we find evidence that the creation of the General Court (then as Court of 
First Instance) improved quality but not speed.

These findings are eminently relevant for future policy debates on court reforms, both within the European Union system and outside it. Our research underlines that targeting improvement of decision-making speed necessarily ceteris paribus impacts negatively quality due to a trade-off between the two. Few reforms, however, appear concerned about both variables at the same time. Moreover, policy-makers should be aware that expending greater resources does not automatically translate into decreased case duration, which tends to be the objective of the vast majority of court reforms. 


\section{References}

Alemanno, A. and Pech, L. (2017), 'Thinking justice outside the docket: A critical assessment of the reform of the EU's court system', Common Market Law Review 54(1), 129-175.

Alter, K. (1998), Explaining National Court Acceptance of European Court Jurisprudence: A Critical Evaluation of Theories of Legal Integration, Hart Publishing.

Basabe-Serrano, S. (2016), 'The quality of judicial decisions in Supreme Courts: A conceptual definition and index applied to eleven latin american countries', Justice System Journal 37(4), 331-347.

Beenstock, M. and Haitovsky, Y. (2004), 'Does the appointment of judges increase the output of the judiciary?', International Review of Law and Economics 24(3), 351-369.

Bielen, S., Peeters, L., Marneffe, W. and Vereeck, L. (2018), 'Backlogs and litigation rates: Testing congestion equilibrium across european judiciaries', International Review of Law and Economics 53, 9-22.

Binford, W. W. H., Greene, P. C., Schmidlkofer, M. C. and Wilsey, R. M. (2007), 'Seeking best practices among intermediate courts of appeal: A nascent journey', J. App. Prac. E Process $\mathbf{9}, 37$.

Butler, G. (2019), 'An interim post-mortem: Specialised courts in the EU judicial architecture after the civil service tribunal', International Organizations Law Review .

Cabrillo, F. and Fitzpatrick, S. (2008), The Economics of Courts and Litigation, Edward Elgar.

Cauthen, J. N. and Latzer, B. (2008), 'Why so long? explaining processing time in capital appeals', Justice System Journal 29(3), 298-312.

Colombet, H. and Gouttefangeas, A. (2013), 'La qualité des décisions de justice. quels critères ?', Droit et société $\mathbf{8 3}(1), 155-176$.

Dalla Pellegrina, L. (2008), 'Court delays and crime deterrence', European Journal of Law and Economics 26(3), 267-290.

Dimitrova-Grajzl, V., Grajzl, P., Sustersic, J. and Zajc, K. (2012), 'Court output, judicial staffing, and the demand for court services: Evidence from slovenian courts of first instance', International Review of Law and Economics 32(1), 19-29. 
Djankov, S., La Porta, R., Lopez-de Silanes, F. and Shleifer, A. (2003), 'Courts', Quarterly Journal of Economics $\mathbf{1 1 8}(2), 453-517$.

Dyevre, A., Glavina, M. and Atanasova, A. (2019), 'Who refers most? institutional incentives and judicial participation in the preliminary ruling system', Journal of European Public Policy .

Easson, A. (1989), 'Legal approaches to European integration: The role of court and legislator in the completion of the European common market', Journal of European Integration 12, 101-119.

Engel, C. and Weinshall, K. (2019), 'Manna from heaven for judges. judges' reaction to a quasi-random reduction in caseload', mimeo.

European Court of Auditors (2017), 'Performance review of case management at the Court of Justice of the European Union', available at http://publications.europa.eu/webpub/eca/special-reports/ court-of-justice-14-2017/en/, assessed on 20/08/2019.

Falavigna, G., Ippoliti, R., Manello, A. and Ramello, G. B. (2015), 'Judicial productivity, delay and efficiency: A directional distance function (ddf) approach', European Journal of Operational Research 240(2), 592-601.

Fjelstul, J. C. and Carrubba, C. J. (2018), 'The politics of international oversight: Strategic monitoring and legal compliance in the European Union', American Political Science Review 112(3), 429-445.

Forwood, N. (2000), 'The evolving role of the Court of First Instance of the European Communities: Some Comments on the Changes Agreed at Nice as they Affect the Judicial Architecture of the Community courts', Cambridge Yearbook of European Legal Studies 3, 139-149.

Gomes, A., de Aquino Guimaraes, T. and Akutsu, L. (2016), The relationship between judicial staff and court performance: Evidence from brazilian state courts, in 'IJCA', Vol. 8, HeinOnline, p. 12.

Hadroušek, D. and Smolek, M. (2015), 'Solving the european union's general court', European Law Review 40(2), 188-206.

Henisz, W. J. (2000), 'The institutional environment for economic growth', Economics E Politics 12(1), 1-31.

Jacqué, J. P. and Weiler, J. (1990), 'On the Road to European Union - a new judicial architecture: An agenda for the intergovernmental conference', Common Market Law Review 27, 185-207. 
Jonski, K. and Mankowski, D. (2014), Is sky the limit-revisiting exogenous productivity of judges argument, in 'IJCA', Vol. 6, HeinOnline, p. 53.

Kennedy, T. (1989), 'The essential minimum: the establishment of the Court of First Instance', European Law Review 14(1), 7-29.

Koopmans, T. (1991), 'The birth of European law at the cross-roads of legal traditions', American Journal of Comparative Law 39(3), 493-507.

Krenn, C. (2018), 'Self-government at the Court of Justice of the European Union: A bedrock for institutional success', German Law Journal 19(7), 2007-2030.

Lampach, N. and Dyevre, A. (2019), 'Choosing for Europe: Judicial incentives and legal integration in the European Union', European Journal of Law and Economics .

URL: https://doi.org/10.1007/s10657-019-09622-9

Lavranos, N. (2005), 'The new specialised courts within the European judicial system', European Law Review $\mathbf{3 0}(2), 261-272$.

Marciano, A., Melcarne, A. and Ramello, G. B. (2019), 'The economic importance of judicial institutions, their performance and the proper way to measure them', Journal of Institutional Economics 15(1), 81-98.

Melcarne, A. and Ramello, G. (2016), 'Justice delayed, growth denied: Evidence from a comparative perspective', Unpublished manuscript .

Mitsopoulos, M. and Pelagidis, T. (2010), 'Greek appeals courts' quality analysis and performance', European Journal of Law and Economics 30(1), 17-39.

Ovádek, M. (2017), 'At last! reaching the remedy for delay after a long ride through the EU judicial system', Maastricht Journal of European and Comparative Law 24, 438-447.

Pavone, T. and Kelemen, D. (2019), 'The evolving judicial politics of European Integration: The European Court of Justice and national courts revisited', European Law Journal .

Rasmussen, H. (2000), 'Remedying the crumbling EC judicial system', Common Market Law Review 37(5), 1071-1112. 
Rasmussen, M. (2014), 'Revolutionizing European Law: A History of the Van Gend en Loos judgment', International Journal of Constitutional Law 12(1), 136-163.

Rosales-López, V. (2008), 'Economics of court performance: an empirical analysis', European Journal of Law and Economics 25(3), 231-251.

Sarmiento, D. (2017), 'The reform of the General Court: An exercise in minimalist (but radical) institutional reform', Cambridge Yearbook of European Legal Studies 19, 236-251.

Schermers, H. G. (1988), 'The European Court of First Instance', Common Market Law Review 25, 541-558.

Scorey, D. W. (1996), 'A new model for the Communities' judicial architecture in the new Union', European Law Review 21(3), 224-231.

Seidman, L. S. (1989), 'Complements and substitutes: The importance of minding p's and q's', Southern Economic Journal 56(1), 183.

Slynn, G. (1989), 'Court of First Instance of the European Communities', Northwestern Journal of International Law and Business pp. 63-68.

Turner, C. and Muñoz, R. (2000), 'Revising the judicial architecture of the European Union', Yearbook of European Law 19, 1-93.

Tyler, T. R. (2001), 'Public trust and confidence in legal authorities: What do majority and minority group members want from the law and legal institutions?', Behavioral Sciences 65 the Law 19(2), 215-235.

URL: https://onlinelibrary.wiley.com/doi/abs/10.1002/bsl.438

Valentine, D. G. (1955), The Court of Justice of the European Coal and Steel Community, Martinus Nijhoff.

van der Woude, M. (2012), 'Judicial reform and reasonable delay', Journal of European Competition Law \& Practice 3(2), 123-125.

Van Ginderachter, E. (1989), 'Le Tribunal de première instance des Communautés européennes - un nouveau-né prodige ?', Cahiers de droit européen $\mathbf{9}, 542-551$.

Vereeck, L. and Mühl, M. (2000), 'An economic theory of court delay', European Journal of Law and Economics $\mathbf{1 0}(3), 243-268$. 
Voigt, S. (2016), 'Determinants of judicial efficiency: A survey', European Journal of Law and Economics 42(2), 183-208.

Weder, B. (1995), 'Legal systems and economic performance: the empirical evidence', World Bank, Judicial Reform in Latin America and the Caribbean pp. 21-26.

Weiler, J. H. (1994), 'A quiet revolution: The European Court of Justice and Its Interlocutors', Comparative Political Studies 26(4), 510-534.

Zheng, A. (2016), 'The faceless court', University of Pennsylvania Journal of International Law 38(1), 71-135. 